\title{
An Analysis of the Effects of Crash Factors and Precrash Actions on Side Impact Crashes at Unsignalized Intersections
}

\author{
Emmanuel Kofi Adanu $\mathbb{D D}^{1}{ }^{1}$ Xiaobing Li $\left(\mathbb{D},{ }^{1}\right.$ Jun Liu $\mathbb{D},{ }^{2}$ and Steven Jones ${ }^{2}$ \\ ${ }^{1}$ Alabama Transportation Institute, The University of Alabama, Tuscaloosa, AL 35487, USA \\ ${ }^{2}$ Department of Civil, Construction and Environmental Engineering, The University of Alabama, Tuscaloosa, AL 35487, USA
}

Correspondence should be addressed to Emmanuel Kofi Adanu; ekadanu@crimson.ua.edu

Received 12 December 2020; Revised 16 March 2021; Accepted 25 March 2021; Published 5 April 2021

Academic Editor: Nirajan Shiwakoti

Copyright ( $) 2021$ Emmanuel Kofi Adanu et al. This is an open access article distributed under the Creative Commons Attribution License, which permits unrestricted use, distribution, and reproduction in any medium, provided the original work is properly cited.

\begin{abstract}
Annually, side impact crashes contribute to a significant proportion of road fatalities. These crashes typically occur as a result of traffic violations at intersections. This study contributes to efforts in addressing side impact crashes at unsignalized intersections by performing a path analysis to unravel some behavioral trajectories through which these crashes occur. The study further investigated how these behavioral pathways influence the severity of the crashes. Crashes that occurred at unsignalized four-way intersections and $\mathrm{T}$-junctions in Alabama were used for model estimations. Three precrash actions, failed to yield right-of-way at the stop sign, failed to yield right-of-way at a turn, and running stop sign, were considered. The model estimation results reveal that some of the crash factors were more associated with certain precrash factors but not others at either four-way intersections or $\mathrm{T}$-junctions or both. It was observed that side impact crashes that occurred under daylight conditions at four-way intersections, for instance, were less likely to involve running a stop sign but more likely to involve failure to yield at the stop sign and failure to yield right-of-way at a turn, but under dark and unlit roadway conditions, the at-fault drivers were more likely to run a stop sign or fail to yield at a stop sign but less likely to be involved in failure to yield right-of-way at a turn. This approach to injury severity analysis uncovers complex underlying relationships between precrash actions, other contributing factors, and crash outcomes.
\end{abstract}

\section{Introduction}

In 2018, side impact crashes accounted for about $23 \%$ of passenger vehicle occupant deaths in the U.S. Side impact crashes tend to cause serious injuries due to their possible effects on multiple body parts, including the head, neck, ribs, arms, hips, and legs [1]. Even at lower speeds, side impact crashes often lead to serious injuries. Studies have shown that side impact crashes, where the initial point is the driver side, are more likely to result in serious and fatal injuries than those that impact the far side. Side impact crashes often occur at intersections where one driver fails to yield the right-of-way. Efforts to reduce the occurrence of these crashes have led to the installation of various traffic control devices at intersections. While newer vehicle models have many safety features such as airbags, seatbelts, and bumpers, to protect occupants from frontal and rear-end collisions, side impact car crashes leave occupants relatively unprotected. Presently, some vehicles have side curtain airbags, but most vehicles on the roads offer no protection from side impact crashes besides the car door.

Side impact crashes typically occur at intersections, and the frequency and severity of these crashes depend on the type of intersection [2, 3]. Generally, intersections are classified based on the number and configuration of the approaches (such as four-way (four-leg) intersections and Tjunctions) and the type of traffic control (e.g., signalized and unsignalized). Studies have shown that the injury severity of crashes differs significantly across intersection types based on the traffic control present (e.g., stop/yield sign-controlled, traffic signals, and no traffic control) [4]. While traffic signals dictate the flow of traffic through signalized intersections, unsignalized intersections rely on traffic control signs and/or driver behavior to regulate the flow of traffic. As such, the 
location, configuration, and type of traffic control at intersections affect stop/yield sign violation rates. Although these factors have been observed to be associated with crashes, driver and road user behaviors at intersections play even bigger roles in crash occurrence and crash outcomes. For instance, failure to stop or yield at unsignalized intersections (right-of-way violations) or running red light at signalized intersections increases the chances of a collision. These right-of-way violations are more likely to occur under certain roadway and traffic conditions and are often pronounced among certain driver populations $[4,5]$.

Previous studies have found some contributing factors to the injury severity of unsignalized intersection crashes. These crash contributing circumstances include crash-level factors: traffic volume, geometric characteristics, rural or urban, time, weather, lighting condition, and road grade; vehicle-level factors: vehicle type, model, and age; and person-level factors: driver gender and age, seatbelt usage, and drug-/alcohol-impaired. For instance, Pai [6] analyzed the injury severity of motorcyclists in angle crashes at $\mathrm{T}$ junctions and found that the injuries of motorcyclists were greatest when the motorcycle from the major roads crashed into cars from the minor roads. Haleem and Abdel-Aty [7] examined the injury severity of crashes that occurred at unsignalized intersections and found that young and very young at-fault drivers were associated with the least fatal probability compared to other age groups. Wang et al. [8] observed that stop-controlled intersections, one-lane approaches, helmet usage, and lower speed limits are associated with decreased injury severity, whereas older (age $>55$ ) drivers and bicyclists, road users aged less than 16 years, bicyclists, foggy and rainy weather, inadequate use of lights in dark conditions, and wet road surfaces are associated with increased injury severity at uncontrolled intersections. Also, Haleem et al. [4] found that middle and very old pedestrians, at-fault pedestrians, vans, dark lighting condition, and higher speed limit are associated with higher pedestrian severity risk at unsignalized intersections. Li et al. [9] found that compared to intersections that have no traffic control devices, stop/yield sign-controlled intersections record decreased levels of injury severities and fatalities; however, the association was not as strong as that of the signal-controlled intersections. A study conducted by Wahi et al. [10] indicated that cyclists at stop/yield sign-controlled intersections were more severely injured if they were at fault in the crash occurrence. With respect to the intersection approach types, Wang et al. [11] found that compared to fiveor-more-leg intersections, four-leg and T-junction intersections were both found to be associated with increased crash injury severity; and the estimated coefficients of these two intersection types indicate that the magnitude of association is higher for four-leg intersections.

Considering that side impact crashes occur primarily as a result of road user behaviors such as traffic law violations, this study performs a behavioral path analysis to understand what factors influence driver behaviors at unsignalized intersections and how these factors influence the severity of side impact crashes. As such, this paper quantifies the effects of various crash contributing factors, such as speeding, through precrash traffic violation behaviors, such as failure to yield right-of-way at a stop sign, at unsignalized four-way intersections and T-junctions in Alabama. This would allow for the understanding of how direct crash contributing factors (such as speeding) influence crash outcomes under different precrash conditions (e.g., failure to yield or failure to stop) at unsignalized intersections. Unraveling the location type, association between direct crash contributing factors and the precrash actions that drivers engage in, and the driver populations that may be at increased risk of such behaviors would provide additional context to improve traffic safety. This approach provides an additional context to viewing the combined effects of crash factors and precrash actions on crash outcomes. The study outcomes are therefore expected to provide the necessary safety knowledge of driver behaviors and help to develop countermeasures that can reduce the incidence and severity of side impact crashes at unsignalized intersections.

\section{Methodology}

Previous crash injury severity studies have explored the associations between various factors, including precrash actions such as failure to yield right-of-way, and crash injury severities using various discrete-outcome modeling techniques (see [12,13] for injury severity methodology reviews). These studies reveal the direct relationships between various crash factors and injury severity outcomes of different crash types. Beyond the direct relationships between crash contributing factors and crash outcomes, this study investigates indirect relationships among these contextual contributing factors and precrash actions to model behavioral pathways illustrated in Figure 1.

The behavioral pathways consist of two parts and are defined by two different models: association between crash contributing factors and precollision actions and the relationships between precrash actions and crash injury severity. The behavioral pathway analysis based on the precrash behaviors identified by primary contributing circumstances at either a four-way intersection or a T-junction involved a quantitative process of combining direct and indirect marginal effects from the injury severity model and the precrash behavior model.

This paper applies path analysis to quantify the behavioral pathways and quantitatively combine direct and indirect relationships among contextual contributing factors $(X)$, precrash actions $\left(Y_{1}\right)$, and crash injury severity $\left(Y_{2}\right)$ as defined by equations (1) and (2) $[14,15]$ :

$$
\begin{aligned}
& Y_{1}=\alpha_{1}+\beta_{1} X \\
& Y_{2}=\alpha_{2}+\beta_{2} X+\gamma Y_{1} .
\end{aligned}
$$

Equations (1) and (2) represent linear-form models to estimate the nature of the relationship $\beta_{1}$ between crash contributing factors $X$ and precrash action $Y_{1}$ and to express direct relationships $\beta_{2}$ between crash injury severity $Y_{2}$ and crash contributing factors $X$ and precrash action $Y_{1}$. This ensures that the direct effects of the contextual contributing 


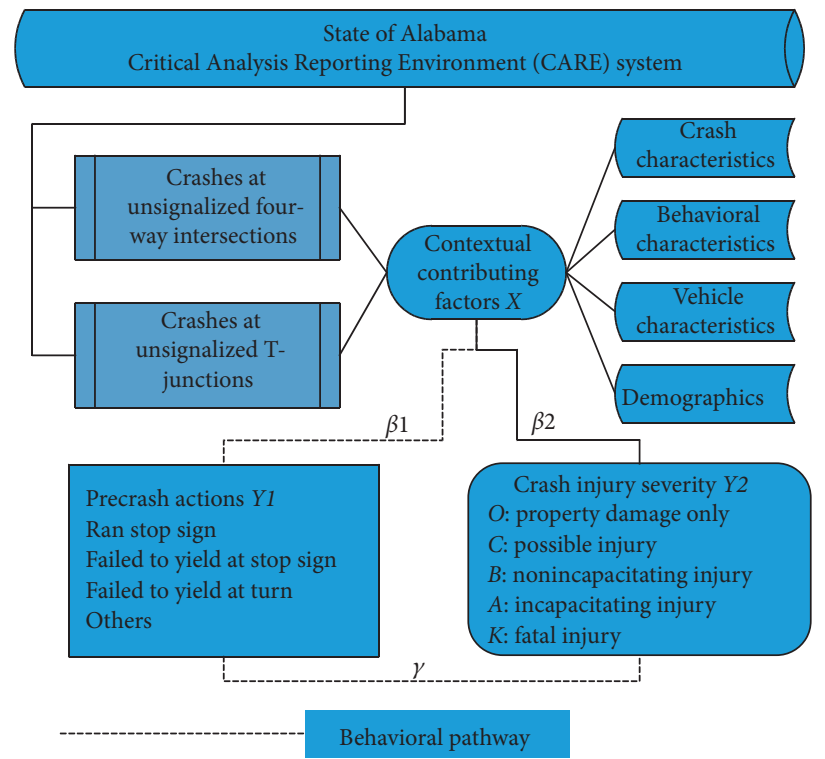

Figure 1: Conceptual workflow for the behavioral pathway of injury severity models.

factors on crash injury severity are captured together with their influence on precrash actions. The two are then connected by $\gamma$.

Equation (1) expresses the relationship between precrash action and crash contributing factors. Multinomial logistic (MNL) models were initially developed to estimate the correlates of precrash actions. To account for unobserved heterogeneity across observations, random-parameter models were further developed to allow estimates to vary across observations, which would improve the model performance [16-22]. The random-parameter MNL model is estimated by predicting the probability of one possible precrash action given a set of contributing factors:

$$
\operatorname{Pr}\left(Y_{1}=i\right)=\frac{\exp \left(\alpha_{1}^{(i)}+\beta_{1}^{(i)}+Z_{1}^{(i)} U\right)}{\sum_{1}^{n} \exp \left(\alpha_{1}^{(i)}+\beta_{1}^{(i)}+Z_{1}^{(i)} U\right)},
$$

where $Y_{1}$ is the response variable (i.e., precrash action); $i$ is one of the three possible precrash actions; $\alpha_{1}^{(i)}$ is the constant term in estimates corresponding to precrash action $i$; $X$ represents a vector of explanatory variables (i.e., contributing factors); $\beta_{1}^{(i)}$ is a set of fixed coefficients of $X$ corresponding to precrash action $i$; $U$ is a vector of variables with a random parameter; and $Z_{1}^{(i)}$ is a set of random parameters of $U$ corresponding to precrash action $i$.

The estimation of a MNL model produces -1 sets of coefficients, where is the number of discrete choices. Each set of coefficients can be used to predict the probability of one corresponding pre-crash action, and to indicate the relationship between contextual contributing factors and a specific pre-crash action.

Equation (2) models the correlates of crash injury severity, similar to traditional injury severity analyses. Given the ordinal nature of injury severity, this study used ordered logistic modeling techniques to show how contributing factors (plus precrash behavior) are associated with crash injury severity. Again, to account for unobserved heterogeneity across crash observations, random-parameter ordered logistic models were estimated as

$$
\operatorname{Pr}\left(Y_{2}=c\right)=\frac{1}{1+\exp \left(-k_{c}+\beta_{2} X+\gamma Y_{1}+Z_{2} U\right)}-\frac{1}{1+\exp \left(-k_{c-1}+\beta_{2} X+\gamma Y_{1}+Z_{2} U\right)}
$$

where $Y_{2}$ is the crash injury severity; $c$ is the specific level of injury severity, $c=1 \sim 5$ possible levels of injury severity (fatal injury, incapacitating injury, nonincapacitating injury, possible injury, and no injury); $k_{c}$ is the threshold value for injury severity level $c, k_{0}=-\infty$ and $k_{5}=+\infty$; $X$ is a vector of contributing factors excluding precrash action; $\beta_{2}$ is a set of coefficients corresponding to $X ; Y_{1}$ is the precrash action, treated as an explanatory variable; $\gamma$ is the coefficient of $Y_{1} ; U$ is a vector of variables with a random parameter; and $Z_{2}$ is a set of random parameters of $U$.
The model parameters are estimated by maximizing the likelihood. A likelihood-ratio test is performed to compare the random-parameter model with the regular logistic model that does not account for the unobserved heterogeneity. The test is done by calculating the ratio of log likelihoods of two models:

$$
L R=-2 L n \frac{L L_{\text {regular }}}{L L_{\text {random-parameter }}},
$$

where $L L_{\text {regular }}$ is the estimated log likelihood of the regular model and $L L_{\text {random-parameter }}$ is the log likelihood of the 
random-parameter model. The ratio is assumed to have an approximate $\chi^{2}$ distribution with $k$ degrees of freedom. $k$ is the number of model parameters. If $\chi^{2}$ is larger than the 95percentile value in the $\chi^{2}$ distribution table with $\mathrm{k}$ degrees of freedom, a $p$ value is given to indicate how the randomparameter models perform in comparison with the fixedeffect models.

The unit of coefficients in both multinomial and ordered logistic models is log of the odds, showing the change of log of the odds of one response with one unit change in one explanatory variable if other variables are held constant. To quantify the behavioral pathway (i.e., combining $\beta_{1}$ and $\gamma$ ), the marginal effects of explanatory variables are estimated based on the model coefficients. Marginal effects show the probability change of one response with one unit change in one explanatory variable if the other variables are held constant. For multinomial logistic models, marginal effects are computed as

$$
\frac{\partial \operatorname{Pr}\left(Y_{1}=i\right)}{\partial X}=\frac{\exp \left(f^{(i)}(X, U)\right)\left(\beta_{1}^{(i)}\right)^{\prime}+\exp \left(f^{(i)}(X, U)\right)\left(\sum_{j=1}^{n} \exp \left(f^{(i)}(X, U)\right)\left(\left(\beta_{1}^{(i)}\right)^{\prime}-\left(\beta_{1}^{(j)}\right)^{\prime}\right)\right)}{\left[1+\sum_{j=1}^{n} \exp \left(f^{(i)}(X, U)\right)\right]^{2}}
$$

where $\quad f^{(i)}(X, U)=\alpha_{1}^{(i)}+\beta_{1}^{(i)} X+Z_{1}^{(i)} U$ and $f^{(j)}(X, U)=\alpha_{1}^{(j)}+\beta_{1}^{(j)} X+Z_{1}^{(j)} U$. For ordered logistic models, marginal effects can be estimated as

$$
\frac{\partial \operatorname{Pr}\left(Y_{2} \leq c\right)}{\partial X}=\frac{\exp \left(-k_{c}+\beta_{2} X+\gamma Y_{1}+Z_{2} U\right)}{\left[1+\exp \left(-k_{c}+\beta_{2} X+\gamma Y_{1}+Z_{2} U\right)\right]^{2}} \beta_{2}^{\prime} .
$$

The marginal effects of correlates of precrash actions and their relationships with crash injury severity can be combined as the indirect relationship between contributing factors and injury severity through precrash actions as

$$
\text { indirect } \mathrm{ME} \text { of } X \text { on } Y_{2}=\left(\mu_{X}+\mathrm{ME} \text { of } X \text { on } Y_{1}\right) *\left(\mu_{Y_{1}}+\operatorname{ME} \text { of } Y_{1} \text { on } Y_{2}\right)-\mu_{X} * \mu_{Y_{1}} \text {, }
$$

where ME represents marginal effects; $\mu_{X}$ is the probability of the outcomes of $Y_{1}$ (i.e., precrash actions) when $X$ is at its base; and $\mu_{Y_{1}}$ is the probability of the outcomes of $Y_{2}$ (i.e., crash injury severity) when $Y_{1}$ is at its base. The calculation example is shown in the results section. Direct marginal effects of contributing factors are calculated based on equation (6) from the injury severity model. The total marginal effects of contributing factors on crash injury severity are then given by

total ME on $Y_{2}=\operatorname{direct} \mathrm{ME}$ of $X$ on $Y_{2}+$ indirect ME of $X$ on $Y_{2}$.

\section{Data and Empirical Setting}

The study was based on 2014-2018 crash data obtained from the Critical Analysis Reporting Environment (CARE) system developed by the Center for Advanced Public Safety at the University of Alabama. This is the primary database where crash records input directly by all traffic safety law enforcement officers in the state of Alabama are maintained. The CARE database serves as the primary source of historical crash data for research and policy decision-making in the state of Alabama. The database was queried to select crashes that occurred at four-way intersections and T-junctions.

Observations with missing or ambiguous values were omitted from the original dataset before performing the model estimation. This yielded a total of 13,910 observed crashes at four-way intersections and 10,750 observed crashes at T-junctions. These crashes include both twovehicle crashes and multivehicle crashes. This study used three main precrash actions (with a fourth category forming the basis for comparison): ran stop sign, failed to yield at stop sign, failed to yield at turn, and "other behaviors." CARE distinguishes failure to yield right-of-way from ran stop sign based on whether the vehicle came to a stop. If the vehicle did not come to a stop, the "Ran" code is applied. However, if the vehicle came to a stop but then proceeded to pull out into the intersection anyway, this is classified as failed to yield. These three main precrash actions were selected because they contributed to more than $73 \%$ of the crashes, and the rest of the precrash actions each contribute to less than $5 \%$ of the crashes. Also, five crash outcomes were used: fatal injury, incapacitating injury, nonincapacitating injury, possible injury, and property damage only. The injury severity assigned to a crash corresponds to the highest severity recorded in situations where multiple severities were recorded.

The descriptive statistics of precrash actions (Tables 1 and 2) show that failure to yield right-of-way at a stop sign contributed to the highest number of crashes at both fourway intersections and $\mathrm{T}$-junctions. While failure to yield right-of-way at a turn accounted for $6.9 \%$ of the crashes at four-way intersections, it was responsible for $17.8 \%$ of the crashes at $\mathrm{T}$-junctions. Also, running a stop sign resulted in only $4.1 \%$ of the crashes that occurred at $\mathrm{T}$-junctions but accounted for $12.3 \%$ of the crashes at four-way intersections. 
In terms of crash outcomes, the side impact crashes that occurred at four-way intersections recorded a higher proportion of some injury in comparison with those that occurred at T-junctions.

Table 3 presents the descriptive statistics of the explanatory variables that were used in model estimation. Notably, a higher proportion of rural side impact crashes occurred at four-way intersections, whereas more of the urban crashes occurred at T-junctions. Similarly, a higher percentage of the crashes that happened in residential areas occurred at four-way intersections, whereas more of those that happened at shopping centers occurred at T-junctions. Overall, the distributions of the crashes by various factors are similar for both four-way intersections and T-junctions, as shown in Table 3.

\section{Results and Discussion}

4.1. Model Results Overview. Tables 4-7 present the model estimation results for precrash actions and crash factors and crash injury severity and crash factors for four-way intersections and T-junctions. The marginal effects of the explanatory variables are also presented in these tables. The model estimation results reveal that some of the crash factors were more associated with certain precrash factors but not others at either four-way intersections or T-junctions or both. For instance, Table 4 shows that side impact crashes that occurred under daylight conditions at four-way intersections were less likely to involve running a stop sign by $0.61 \%$ but more likely to involve failure to yield at a stop sign and failure to yield right-of-way at a turn by $4.89 \%$ and $0.07 \%$, respectively. Similarly, under dark but lit lighting conditions, the side impact crashes were less likely to involve running a stop sign but more likely to involve failure to yield right-of-way at a stop sign or at a turn. However, under dark and unlit roadway conditions, the at-fault drivers were more likely to run a stop sign or fail to yield at a stop sign but less likely to be involved in the failure to yield right-of-way at a turn. With respect to the direct associations between various crash factors and crash outcomes, the ran stop sign variable, failed to yield at stop sign, and failed to yield at a turn variable increase the probability of fatal injury by $0.43 \%, 0.04 \%$, and $0.06 \%$, respectively. The results further show that side impact crashes that occurred at four-way intersections in residential areas and shopping centers were less likely to record injuries, but those that occurred in open country were more likely to result in some form of injury. Similarly, the relationships between crash factors and injury severity outcomes have been found to have some similarities and differences between four-way intersections and $\mathrm{T}$ junctions. For instance, side impact crashes that involved running a stop sign, failure to yield at a stop sign, and failure to yield at a turn were found to be generally associated with lower injury severity outcomes. At four-way intersections, side impact crashes that occurred in open country were more likely to result in some form of injury, whereas those that occurred in residential areas and at shopping centers were less likely to result in injury outcomes. However, crashes that occurred at $\mathrm{T}$-junctions were more likely to record some form of injury at open country and shopping centers but less likely to result in injury in residential areas. The results further show some similarities and differences in how various factors are associated with precrash actions and injury severities between four-way intersections and $\mathrm{T}$ junctions. For instance, side impact crashes that occurred at T-junctions in the open country, residential areas, and shopping centers were more likely to involve failure to yield at a turn, whereas the crashes that occurred at four-way intersections were less likely to involve failure to yield at a turn in the open country and shopping centers but not residential areas. To have a better understanding of how various crash factors are associated with side impact crash outcomes when drivers engage in certain precrash actions at four-way intersections and T-junctions, the total marginal effects are computed through the behavioral pathways.

4.2. Four-Way Intersection Behavioral Pathway. The marginal effect of a variable (e.g., crash in the urban area) measures the change in the percentage point of the probability of one response outcome (e.g., a particular precrash behavior-ran stop sign or $K$-fatal injury) compared to the probability of this outcome when this variable is set at its base (e.g., curved roadway or vertical roadway alignment). The four-way intersection injury severity model provides direct marginal effects (ME) of contributing factors (e.g., precrash behaviors) on crash injury severity, while the random-parameter multinomial precrash action model estimates the marginal effects of contributing factors on precrash behaviors. If some of the precrash behaviors are significantly correlated with crash injury severity, then some of the contributing factors (e.g., speeding and DUI) might introduce indirect marginal effects through these precrash behaviors that are statistically significant in the injury severity model.

Table 8 presents the total ME results of four-way intersection behavioral pathway analysis by synthesizing and quantifying the direct and indirect MEs of contributing factors on crash injury severity. MEs based on insignificant model estimations ( $p$ value $>0.1$ ) are omitted, and their MEs are assumed to be 0 . In the injury severity model, the estimates of "ran stop sign" and "failed to yield at stop sign" are statistically significant ( $p$ value $\leq 0.1$ ), but not "failed to yield at turn." Thus, the total MEs are quantified through both precrash behaviors "ran stop sign" and "failed to yield at stop sign." Therefore, in Table $8, Y_{1}$ refers to the precrash behaviors of at-fault driver "ran stop sign" and "failed to yield at stop sign," indicating two significant behavioral pathways. The contributing factors in the injury severity model have their associated MEs on each level of crash injury severity, and Table 4 clearly indicates that MEs on " $O$ : property damage only" have opposite signs compared to MEs on other four higher levels of injury severity (i.e., " $C$ : possible injury," " $B$ : nonincapacitating injury," " $A$ : incapacitating injury," and " $K$ : fatal injury"). This study combines the MEs of four injury severity levels, which are considered as the direct MEs of contributing factors on the probability of $K A B C$ injury. The notes in Table 8 present more details regarding other notations and abbreviations. 
TABLE 1: Descriptive statistics of precrash action and injury severity of four-way intersection crashes.

\begin{tabular}{lccc}
\hline Variable & & Frequency & Percent \\
\hline \multirow{3}{*}{ Precrash action } & Ran stop sign & 1704 & 12.3 \\
& & & \\
\cline { 2 - 4 } Others & Failed to yield at stop sign & 6407 & 60.4 \\
& Failed to yield at turn & 964 & 6.9 \\
& 2835 & 20.4 & 64.0 \\
Crash injury severity & O: property damage only & 8907 & 13.6 \\
& C: possible injury & 1894 & 13.4 \\
& B: nonincapacitating injury & 1858 & 8.2 \\
& A: incapacitating injury & 1137 & 0.8 \\
\hline
\end{tabular}

TABLE 2: Descriptive statistics of precrash action and injury severity of T-junction crashes.

\begin{tabular}{lccc}
\hline Variable & & Frequency & Percent \\
\hline \multirow{3}{*}{ Precrash action } & Ran stop sign & 442 & 4.1 \\
& & & 51.9 \\
\cline { 2 - 4 } Others & Failed to yield at stop sign & 5584 & 17.8 \\
& Failed to yield at turn & 1918 & \\
& 2806 & 26.1 & 69.3 \\
Crash injury severity & C: possible injury & 1347 & 12.7 \\
& B: nonincapacitating injury & 1362 & 175 \\
& A: incapacitating injury & 697 & 6.5 \\
& K: fatal injury & 69 & 0.6 \\
\hline
\end{tabular}

TABLE 3: Descriptive statistics of variables used in model estimation.

\begin{tabular}{|c|c|c|c|c|}
\hline \multirow{2}{*}{ Variable } & \multicolumn{2}{|c|}{ Four-way intersection } & \multicolumn{2}{|c|}{ T-junction } \\
\hline & Frequency & Percent (\%) & Frequency & Percent (\%) \\
\hline \multicolumn{5}{|l|}{ Crash location } \\
\hline Rural & 3756 & 27.0 & 2593 & 24.1 \\
\hline Urban & 10,154 & 73.0 & 8157 & 75.9 \\
\hline \multicolumn{5}{|l|}{ Crash location } \\
\hline Other crash locations & 409 & 2.9 & 437 & 4.1 \\
\hline Open country & 4004 & 28.8 & 2765 & 25.7 \\
\hline Residential area & 4378 & 31.5 & 3055 & 28.4 \\
\hline Shopping center & 5119 & 36.8 & 4493 & 41.8 \\
\hline \multicolumn{5}{|l|}{ Roadway condition } \\
\hline Other roadway conditions & 70 & 0.5 & 57 & 0.5 \\
\hline Dry roadway condition & 12,046 & 86.6 & 9127 & 84.9 \\
\hline Wet roadway condition & 1794 & 12.9 & 1566 & 14.6 \\
\hline \multicolumn{5}{|l|}{ Lighting condition } \\
\hline Other lighting conditions & 536 & 3.9 & 443 & 4.1 \\
\hline Daylight & 11,292 & 81.2 & 8694 & 80.9 \\
\hline Dark without lighting & 1359 & 9.8 & 1046 & 9.7 \\
\hline Dark with lighting & 723 & 5.2 & 567 & 5.3 \\
\hline \multicolumn{5}{|l|}{ Roadway curvature and grade } \\
\hline Straight level road & 11,898 & 85.5 & 8352 & 77.7 \\
\hline Straight road with grade & 1781 & 12.8 & 1891 & 17.6 \\
\hline Curved roadway & 231 & 1.7 & 507 & 4.7 \\
\hline \multicolumn{5}{|l|}{ Turn lane } \\
\hline No turn lane & 11,062 & 79.5 & 7497 & 69.7 \\
\hline Turn lane present & 2848 & 20.5 & 3253 & 30.3 \\
\hline Traffic control device & & & & \\
\hline
\end{tabular}


TABle 3: Continued.

\begin{tabular}{|c|c|c|c|c|}
\hline \multirow{2}{*}{ Variable } & \multicolumn{2}{|c|}{ Four-way intersection } & \multicolumn{2}{|c|}{ T-junction } \\
\hline & Frequency & Percent (\%) & Frequency & Percent (\%) \\
\hline Functional & 10,935 & 78.6 & 7067 & 65.7 \\
\hline Not functional & 2975 & 21.4 & 3683 & 34.3 \\
\hline \multicolumn{5}{|l|}{ Contributing factor } \\
\hline Speeding & 264 & 1.9 & 248 & 2.3 \\
\hline DUI & 214 & 1.5 & 193 & 1.8 \\
\hline \multicolumn{5}{|l|}{ At-fault driver gender } \\
\hline Female & 7163 & 51.5 & 5327 & 49.6 \\
\hline Male & 6747 & 48.5 & 5423 & 50.4 \\
\hline \multicolumn{5}{|l|}{ At-fault driver age } \\
\hline Other age groups & 1551 & 11.2 & 1128 & 10.5 \\
\hline Less than 22 & 3004 & 21.6 & 2584 & 24.0 \\
\hline Between 22 and 31 & 2917 & 21.0 & 2215 & 20.6 \\
\hline Between 32 and 41 & 1868 & 13.4 & 1374 & 12.8 \\
\hline Between 42 and 51 & 1515 & 10.9 & 1205 & 11.2 \\
\hline Between 52 and 61 & 1593 & 11.5 & 1205 & 11.2 \\
\hline Between 62 and 71 & 1462 & 10.5 & 1039 & 9.7 \\
\hline \multicolumn{5}{|c|}{ Point of initial contact of the causal vehicle } \\
\hline Others & 2576 & 18.5 & 2103 & 19.6 \\
\hline Front passenger side & 1174 & 8.4 & 1035 & 9.6 \\
\hline Back passenger side & 1035 & 7.4 & 798 & 7.4 \\
\hline Bumper & 6496 & 46.7 & 4926 & 45.8 \\
\hline Driver door & 1395 & 10.0 & 936 & 8.7 \\
\hline Passenger side behind the driver & 1234 & 8.9 & 952 & 8.9 \\
\hline \multicolumn{5}{|l|}{ Causal vehicle type } \\
\hline Other vehicles & 921 & 6.6 & 774 & 7.2 \\
\hline Passenger car & 7358 & 52.9 & 5812 & 54.1 \\
\hline Pickup & 2498 & 18.0 & 1853 & 17.2 \\
\hline SUV & 3133 & 22.5 & 2311 & 21.5 \\
\hline \multicolumn{5}{|l|}{ Second vehicle type } \\
\hline Other vehicles & 1256 & 9.0 & 1091 & 10.1 \\
\hline Passenger car & 7036 & 50.6 & 5481 & 51.0 \\
\hline Pickup & 2658 & 19.1 & 1997 & 18.6 \\
\hline SUV & 2960 & 21.3 & 2181 & 20.3 \\
\hline
\end{tabular}

TABLE 4: Random-parameter multinomial logit model of precrash actions for side impact crashes at four-way intersections.

\begin{tabular}{|c|c|c|c|c|c|c|c|c|c|c|}
\hline \multirow{2}{*}{\multicolumn{2}{|c|}{$\begin{array}{l}Y_{1}=\text { precrash action (base: other behaviors) } \\
\text { Variables and description }\end{array}$}} & \multicolumn{3}{|c|}{ Ran stop sign } & \multicolumn{3}{|c|}{$\begin{array}{c}\text { Failed to yield at stop } \\
\text { sign }\end{array}$} & \multicolumn{3}{|c|}{ Failed to yield at turn } \\
\hline & & $\beta$ & ME & $\beta$ & ME & $\beta$ & $\mathrm{ME}$ & & & \\
\hline $\begin{array}{l}\text { Constant } \\
\text { Urban }\end{array}$ & Yes & -1.648 & $* * *$ & & $\begin{array}{c}-0.134 \\
0.067 \\
\end{array}$ & & $-2.06 \%$ & -4.028 & $* * *$ & \\
\hline \multirow{2}{*}{ Crash location } & Open country & 0.013 & & $0.03 \%$ & & & & 0.096 & & $-0.07 \%$ \\
\hline & $\begin{array}{l}\text { Residential area } \\
-0.217\end{array}$ & 0.734 & $\begin{array}{l}* * * \\
-0.47\end{array}$ & 2.61 & & & 0.145 & -0.523 & $\begin{array}{c}* * \\
-0.15 \%\end{array}$ & $0.19 \%$ \\
\hline Roadway condition & Dry & & & & & & & 1.860 & $* *$ & $-3.54 \%$ \\
\hline Wet & & & & & & & 1.874 & $* *$ & $-0.53 \%$ & \\
\hline \multirow{2}{*}{ Lighting condition } & Daylight & -0.096 & & $-0.61 \%$ & 0.423 & $* * *$ & $4.89 \%$ & -0.039 & & $0.07 \%$ \\
\hline & $\begin{array}{c}\text { Dark without lighting } \\
-0.178\end{array}$ & 0.598 & $\begin{array}{c}* * * * \\
-0.15 \% \\
\end{array}$ & $\begin{array}{c}0.37 \% \\
0.037 \\
\end{array}$ & 0.175 & $0.05 \%$ & $\begin{array}{c}0.16 \% \\
-0.129 \\
\end{array}$ & 0.743 & $\begin{array}{l}* * * \\
0.03 \% \\
\end{array}$ & $-0.12 \%$ \\
\hline Roadway geometry & Straight level road & 1.141 & $* * *$ & $12.26 \%$ & 1.472 & $* * *$ & $17.96 \%$ & & & \\
\hline Straight road with grade & 1.345 & $* * *$ & $1.65 \%$ & 1.172 & $* * *$ & $2.28 \%$ & & & & \\
\hline
\end{tabular}


TABle 4: Continued.

\begin{tabular}{|c|c|c|c|c|c|c|c|c|c|c|}
\hline \multirow{2}{*}{\multicolumn{2}{|c|}{$\begin{array}{l}Y_{1}=\text { precrash action (base: other behaviors) } \\
\text { Variables and description }\end{array}$}} & \multicolumn{3}{|c|}{ Ran stop sign } & \multicolumn{3}{|c|}{$\begin{array}{l}\text { Failed to yield at stop } \\
\text { sign }\end{array}$} & \multicolumn{3}{|c|}{ Failed to yield at turn } \\
\hline & & $\beta$ & ME & $\beta$ & ME & $\beta$ & ME & & & \\
\hline \multirow{5}{*}{$\begin{array}{l}\text { Turn lane present } \\
\text { No functioning traffic } \\
\text { control } \\
\text { At-fault driver_speeding } \\
\text { At-fault driver_DUI } \\
\text { Gender }\end{array}$} & Yes & -1.495 & $* * *$ & $-1.38 \%$ & -1.199 & $* * *$ & $-3.54 \%$ & & & \\
\hline & Yes & -1.559 & $* * *$ & $-1.89 \%$ & -2.258 & $* * *$ & $-6.66 \%$ & 1.085 & $* * *$ & $-1.08 \%$ \\
\hline & Yes & & & & -4.024 & $* * *$ & $-0.37 \%$ & -4.219 & $* * *$ & $0.00 \%$ \\
\hline & Yes & -1.899 & $* * *$ & $-0.23 \%$ & -3.734 & $* * *$ & $-0.46 \%$ & -2.793 & $* * *$ & $0.01 \%$ \\
\hline & Male & & & & -0.230 & $* * *$ & $-1.64 \%$ & & & \\
\hline \multirow{5}{*}{ Causal driver age } & 21 years old or younger & 0.197 & & $0.37 \%$ & 0.029 & & $0.09 \%$ & & & \\
\hline & 22 31 years old & 0.269 & $* *$ & $0.53 \%$ & -0.234 & $* *$ & $-0.72 \%$ & & & \\
\hline & $32 \sim 41$ years old & 0.161 & & $0.19 \%$ & -0.127 & & $-0.25 \%$ & & & \\
\hline & $42 \sim 51$ years old & -0.209 & & $-0.17 \%$ & -0.393 & & $-0.63 \%$ & & & \\
\hline & $52 \sim 61$ years old & -0.105 & & $-0.09 \%$ & -0.080 & & $-0.13 \%$ & & & \\
\hline \multirow[t]{2}{*}{$62 \sim 71$ years old } & -0.051 & & $-0.04 \%$ & 0.052 & & $0.08 \%$ & & & & \\
\hline & Front passenger side & 0.601 & $* * *$ & $0.55 \%$ & 0.266 & $* *$ & $0.33 \%$ & -0.724 & $* * *$ & $0.04 \%$ \\
\hline \multirow[t]{3}{*}{ Point of impact } & Back passenger side & 0.362 & $* *$ & $0.27 \%$ & 0.095 & & $0.11 \%$ & -0.444 & $*$ & $0.03 \%$ \\
\hline & Bumper & 0.160 & & $0.51 \%$ & 0.708 & $* * *$ & $4.57 \%$ & 1.003 & $* * *$ & $-1.46 \%$ \\
\hline & Driver door & 0.275 & $* *$ & $0.25 \%$ & 0.209 & $*$ & $0.31 \%$ & 0.435 & $* * *$ & $-0.09 \%$ \\
\hline $\begin{array}{c}\text { Passenger side behind the } \\
\text { driver }\end{array}$ & 0.095 & & $0.07 \%$ & 0.116 & & $0.15 \%$ & 0.117 & & $-0.02 \%$ & \\
\hline \multirow{2}{*}{ Causal vehicle type } & Passenger car & & & & 0.372 & $* * *$ & $2.81 \%$ & 0.342 & $* *$ & $-0.42 \%$ \\
\hline & Pickup & & & & 0.314 & $* * *$ & $0.85 \%$ & 0.124 & & $-0.05 \%$ \\
\hline \multirow[t]{2}{*}{ SUV } & & & & 0.489 & $* * *$ & $1.26 \%$ & 0.291 & $*$ & $-0.14 \%$ & \\
\hline & Passenger car & & & & & & & -0.089 & & $0.10 \%$ \\
\hline Noncausal vehicle type & Pickup & & & & & & & -0.138 & & $0.06 \%$ \\
\hline SUV & & & & & & & -0.296 & $* *$ & $0.12 \%$ & \\
\hline \multirow{2}{*}{$\begin{array}{l}\text { Scale parameters for random } \\
\text { parameters in precrash } \\
\text { actions }\end{array}$} & Straight level road & 1.137 & $* * *$ & & & & & & & \\
\hline & Urban & & & & 1.793 & $* * *$ & & & & \\
\hline \multirow[t]{3}{*}{ Causal vehicle: SUV } & & & & 0.721 & $*$ & & & & & \\
\hline & Number of observations & & & & & 13,910 & & & & \\
\hline & $\begin{array}{c}\text { Log likelihood at zero } L \\
(0)\end{array}$ & & & & & $-19,283$. & 355 & & & \\
\hline \multirow{4}{*}{ Summary statistics } & $\begin{array}{l}\text { Log likelihood at } \\
\text { convergence } L(\beta)\end{array}$ & & & & & $-12,703$. & 943 & & & \\
\hline & Pseudo- $R 2$ & & & & & 0.341 & & & & \\
\hline & $\begin{array}{l}\text { Likelihood-ratio test (vs. } \\
\text { regular multinomial } \\
\text { logit) }\end{array}$ & & & & & rob. $=0$ & 000 & & & \\
\hline & AIC & & & & & 25,556 & & & & \\
\hline
\end{tabular}

Significance at ${ }^{* * *} 1 \% ;{ }^{* *} 5 \% ;{ }^{*} 10 \%$ levels.

TABLE 5: Random-parameter ordered logit model of injury severity for side impact crashes at four-way intersections.

\begin{tabular}{|c|c|c|c|c|c|c|c|c|}
\hline \multirow{2}{*}{\multicolumn{2}{|c|}{$\begin{array}{l}Y_{2}=\text { four-way intersection crash injury severity } \\
\text { Variables and description }\end{array}$}} & \multicolumn{2}{|c|}{$\begin{array}{l}\text { Model } \\
\text { estimates }\end{array}$} & \multicolumn{5}{|c|}{ Marginal effects } \\
\hline & & $\beta$ & O & C & $B$ & $A$ & $K$ & \\
\hline Constant & & 0.042 & & & & & & \\
\hline \multirow{2}{*}{$\begin{array}{l}\text { Precrash actions (base: other } \\
\text { behaviors) }\end{array}$} & Ran stop sign & 0.718 & $* * *$ & $-17.00 \%$ & $4.48 \%$ & $7.37 \%$ & $4.73 \%$ & $0.43 \%$ \\
\hline & $\begin{array}{l}\text { Failed to yield at stop sign } \\
0.123\end{array}$ & 0.092 & $\begin{array}{c}* \\
-2.77 \% \\
\end{array}$ & $\begin{array}{c}-2.03 \% \\
0.88 \% \\
\end{array}$ & $\begin{array}{l}0.67 \% \\
1.16 \% \\
\end{array}$ & $\begin{array}{l}0.85 \% \\
0.66 \% \\
\end{array}$ & $\begin{array}{l}0.47 \% \\
0.06 \% \\
\end{array}$ & $0.04 \%$ \\
\hline Urban & Yes & -0.524 & $* * *$ & $12.01 \%$ & $-3.62 \%$ & $-5.10 \%$ & $-3.02 \%$ & $-0.27 \%$ \\
\hline
\end{tabular}


TABLE 5: Continued.

\begin{tabular}{|c|c|c|c|c|c|c|c|c|}
\hline \multirow{2}{*}{\multicolumn{2}{|c|}{$\begin{array}{l}Y_{2}=\text { four-way intersection crash injury severity } \\
\text { Variables and description }\end{array}$}} & \multicolumn{2}{|c|}{$\begin{array}{l}\text { Model } \\
\text { estimates }\end{array}$} & \multicolumn{5}{|c|}{ Marginal effects } \\
\hline & & $\beta$ & $O$ & C & $B$ & $A$ & K & \\
\hline $\begin{array}{l}\text { Crash location (base: other crash } \\
\text { locations) }\end{array}$ & Open country & 0.286 & $* *$ & $-6.45 \%$ & $2.05 \%$ & $2.72 \%$ & $1.56 \%$ & $0.14 \%$ \\
\hline Residential area & -0.240 & $* *$ & $5.25 \%$ & $-1.78 \%$ & $-2.17 \%$ & $-1.20 \%$ & $-0.10 \%$ & \\
\hline Shopping center & -0.213 & $*$ & $4.67 \%$ & $-1.57 \%$ & $-1.94 \%$ & $-1.07 \%$ & $-0.09 \%$ & \\
\hline $\begin{array}{l}\text { Roadway geometry (base: curved } \\
\text { roadway) }\end{array}$ & Straight level road & 0.143 & $* * *$ & $-3.24 \%$ & $1.03 \%$ & $1.36 \%$ & $0.78 \%$ & $0.07 \%$ \\
\hline Straight road with grade & -0.086 & & $1.89 \%$ & $-0.64 \%$ & $-0.78 \%$ & $-0.43 \%$ & $-0.04 \%$ & \\
\hline Turn lane present & Yes & 0.103 & $* *$ & $-2.31 \%$ & $0.75 \%$ & $0.97 \%$ & $0.55 \%$ & $0.05 \%$ \\
\hline At-fault driver_speeding & Yes & 0.775 & $* * *$ & $-18.66 \%$ & $4.42 \%$ & $8.18 \%$ & $5.55 \%$ & $0.51 \%$ \\
\hline At-fault driver_DUI & Yes & 1.048 & $* * *$ & $-25.39 \%$ & $4.95 \%$ & $11.21 \%$ & $8.43 \%$ & $0.80 \%$ \\
\hline Gender & Male & -0.167 & $* * *$ & $3.71 \%$ & $-1.23 \%$ & $-1.55 \%$ & $-0.86 \%$ & $-0.07 \%$ \\
\hline \multirow{5}{*}{ Causal driver age } & 21 years old or younger & -0.263 & $* * *$ & $5.68 \%$ & $-1.96 \%$ & $-2.34 \%$ & $-1.27 \%$ & $-0.11 \%$ \\
\hline & 22 31 years old & -0.218 & $* * *$ & $4.73 \%$ & $-1.62 \%$ & $-1.95 \%$ & $-1.07 \%$ & $-0.09 \%$ \\
\hline & $32 \sim 41$ years old & -0.259 & $* * *$ & $5.56 \%$ & $-1.93 \%$ & $-2.29 \%$ & $-1.23 \%$ & $-0.11 \%$ \\
\hline & $42 \sim 51$ years old & -0.242 & $* * *$ & $5.19 \%$ & $-1.81 \%$ & $-2.13 \%$ & $-1.15 \%$ & $-0.10 \%$ \\
\hline & $52 \sim 61$ years old & -0.167 & $* *$ & $3.62 \%$ & $-1.24 \%$ & $-1.49 \%$ & $-0.82 \%$ & $-0.07 \%$ \\
\hline $62 \sim 71$ years old & -0.176 & $* *$ & $3.82 \%$ & $-1.31 \%$ & $-1.58 \%$ & $-0.86 \%$ & $-0.07 \%$ & \\
\hline \multirow{4}{*}{ Point of impact } & Front passenger side & -0.356 & $* * *$ & $7.47 \%$ & $-2.67 \%$ & $-3.05 \%$ & $-1.62 \%$ & $-0.14 \%$ \\
\hline & Back passenger side & -0.965 & $* * *$ & $17.93 \%$ & $-7.00 \%$ & $-7.08 \%$ & $-3.55 \%$ & $-0.30 \%$ \\
\hline & Bumper & 0.755 & $* * *$ & $-16.76 \%$ & $5.33 \%$ & $7.03 \%$ & $4.04 \%$ & $0.35 \%$ \\
\hline & Driver door & 0.412 & $* * *$ & $-9.57 \%$ & $2.80 \%$ & $4.09 \%$ & $2.46 \%$ & $0.22 \%$ \\
\hline Passenger side behind the driver & -0.633 & $* * *$ & $12.64 \%$ & $-4.72 \%$ & $-5.08 \%$ & $-2.63 \%$ & $-0.22 \%$ & \\
\hline \multirow{2}{*}{ Causal vehicle type } & Passenger car & -0.138 & $*$ & $3.06 \%$ & $-1.01 \%$ & $-1.28 \%$ & $-0.71 \%$ & $-0.06 \%$ \\
\hline & Pickup & -0.209 & $* *$ & $4.53 \%$ & $-1.55 \%$ & $-1.87 \%$ & $-1.02 \%$ & $-0.09 \%$ \\
\hline \multirow[t]{2}{*}{ SUV } & -0.112 & & $2.47 \%$ & $-0.83 \%$ & $-1.02 \%$ & $-0.57 \%$ & $-0.05 \%$ & \\
\hline & Passenger car & -0.330 & $* * *$ & $7.32 \%$ & $-2.40 \%$ & $-3.05 \%$ & $-1.71 \%$ & $-0.15 \%$ \\
\hline Noncausal vehicle type & Pickup & -0.497 & $* * *$ & $10.40 \%$ & $-3.71 \%$ & $-4.24 \%$ & $-2.26 \%$ & $-0.19 \%$ \\
\hline SUV & -0.289 & 0.819 & $6.21 \%$ & $-2.15 \%$ & $-2.56 \%$ & $-1.39 \%$ & $-0.12 \%$ & \\
\hline \multirow{2}{*}{$\begin{array}{l}\text { Scale parameters for random } \\
\text { parameters } \\
\text { Male }\end{array}$} & Failed to yield at stop sign & 0.523 & $* * *$ & & & & & \\
\hline & 0.950 & $* * *$ & & & & & & \\
\hline $\mathrm{Mu}(01)$ & & 0.819 & $* * *$ & & & & & \\
\hline $\mathrm{Mu}(02)$ & & 2.003 & $* * *$ & & & & & \\
\hline $\mathrm{Mu}(03)$ & & 4.588 & $* * *$ & & & & & \\
\hline \multirow{6}{*}{ Summary statistics } & Number of observations & \\
\hline & Log likelihood at zero $L(0)$ & \multicolumn{7}{|c|}{$-14,882.277$} \\
\hline & $\begin{array}{c}\text { Log likelihood at convergence } L \\
(\beta)\end{array}$ & \multicolumn{7}{|c|}{$-14,116.792$} \\
\hline & Pseudo- $R 2$ & \multicolumn{7}{|c|}{0.051} \\
\hline & $\begin{array}{l}\text { Likelihood-ratio test (vs. regular } \\
\text { ordered logit) }\end{array}$ & \multicolumn{7}{|c|}{ Prob. $=0.000$} \\
\hline & AIC & \multicolumn{7}{|c|}{$28,305.6$} \\
\hline
\end{tabular}

Together, equations (8) and (9) formulate the process to quantitatively combine direct and indirect MEs of contributing factors. Figure 2 illustrates how the total ME of the straight level roadway section at four-way intersections is calculated to be $18.61 \%$, relative to intersections located at curved roadway sections. Other variables can be calculated based on the same logical procedure.
The behavioral pathway analysis indeed reveals extra implications besides the one generated from the traditional injury severity model. For example, crashes that occurred at a four-way intersection with the straight and flat roadway (vs. curved roadway) are $3.24 \%$ more likely to result in some form of injury regardless of the at-fault driver's precrash behavior. However, by adding the indirect effects through the precrash behaviors (e.g., ran stop sign and failed to yield 
TABLE 6: Random-parameter multinomial logit model of precrash actions for side impact crashes at T-junctions.

\begin{tabular}{|c|c|c|c|c|c|c|c|c|c|c|}
\hline \multirow{2}{*}{\multicolumn{2}{|c|}{$\begin{array}{l}Y_{1}=\text { precrash action (base: other behaviors) } \\
\text { Variables and description }\end{array}$}} & \multicolumn{3}{|c|}{ Ran stop sign } & \multicolumn{3}{|c|}{$\begin{array}{c}\text { Failed to yield at stop } \\
\text { sign }\end{array}$} & \multicolumn{3}{|c|}{ Failed to yield at turn } \\
\hline & & $\beta$ & $\mathrm{ME}$ & $\beta$ & ME & $\beta$ & $\mathrm{ME}$ & & & \\
\hline Constant & & -2.349 & $* * *$ & & 0.386 & & & -2.766 & $* * *$ & \\
\hline Urban & Yes & & & & 0.532 & $* * *$ & $4.06 \%$ & & & \\
\hline \multirow{3}{*}{ Crash location } & Open country & & & & 0.260 & & $1.10 \%$ & 0.495 & $* * *$ & $1.46 \%$ \\
\hline & Residential area & & & & -0.045 & & $-0.17 \%$ & 0.117 & & $0.35 \%$ \\
\hline & Shopping center & & & & 0.564 & $* * *$ & $3.00 \%$ & 0.628 & $* * *$ & $3.32 \%$ \\
\hline \multirow[t]{2}{*}{ Roadway condition } & Dry & & & & & & & 1.646 & $* * *$ & $16.60 \%$ \\
\hline & Wet & & & & & & & 1.501 & $* *$ & $2.36 \%$ \\
\hline \multirow[t]{3}{*}{ Lighting condition } & Daylight & -0.179 & & $-0.43 \%$ & & & & & & \\
\hline & Dark without lighting & -1.489 & & $0.42 \%$ & & & & & & \\
\hline & Dark with lighting & 0.175 & & $0.06 \%$ & & & & & & \\
\hline \multirow[t]{2}{*}{ Roadway geometry } & Straight level road & 1.578 & $* * *$ & $3.66 \%$ & 1.107 & $* * *$ & $11.82 \%$ & & & \\
\hline & Straight road with grade & 1.695 & $* * *$ & $1.11 \%$ & 1.018 & $* * *$ & $2.56 \%$ & & & \\
\hline Turn lane present & Yes & -2.718 & 0.819 & $-0.01 \%$ & -0.479 & 0.819 & $-1.90 \%$ & & & \\
\hline No functioning traffic control & Yes & -2.027 & 2.003 & $-1.04 \%$ & -2.959 & 2.003 & $-11.45 \%$ & 0.453 & $* * *$ & $3.02 \%$ \\
\hline At-fault driver_speeding & Yes & & & & -4.840 & 4.588 & $-0.31 \%$ & -3.299 & $* * *$ & $2.36 \%$ \\
\hline At-fault driver_DUI & Yes & -0.894 & $* * *$ & $-0.07 \%$ & -3.952 & $* * *$ & $-0.40 \%$ & -2.146 & $* * *$ & $-0.20 \%$ \\
\hline Gender & Male & -0.696 & & $1.53 \%$ & & & & & & \\
\hline \multirow[t]{6}{*}{ At-fault driver age } & 21 years old or younger & & & & -0.082 & & $-0.27 \%$ & -0.097 & & $-0.26 \%$ \\
\hline & $22 \sim 31$ years old & & & & -0.412 & $* * *$ & $-1.17 \%$ & -0.203 & $*$ & $-0.49 \%$ \\
\hline & $32 \sim 41$ years old & & & & -0.558 & $* * *$ & $-1.00 \%$ & -0.336 & $* * *$ & $-0.49 \%$ \\
\hline & $42 \sim 51$ years old & & & & -0.372 & $* * *$ & $-0.58 \%$ & -0.187 & & $-0.26 \%$ \\
\hline & $52 \sim 61$ years old & & & & -0.444 & $* * *$ & $-0.71 \%$ & -0.354 & $* * *$ & $-0.45 \%$ \\
\hline & $62 \sim 71$ years old & & & & -0.245 & $*$ & $-0.33 \%$ & -0.105 & & $-0.12 \%$ \\
\hline \multirow[t]{5}{*}{ Point of impact } & Front passenger side & 0.665 & $* * *$ & $0.32 \%$ & & & & -0.542 & $* * *$ & $-0.33 \%$ \\
\hline & Back passenger side & 0.314 & & $0.09 \%$ & & & & -0.714 & $* * *$ & $-0.29 \%$ \\
\hline & Bumper & -0.168 & & $-0.18 \%$ & & & & 0.820 & $* * *$ & $5.55 \%$ \\
\hline & Driver door & 0.284 & & $0.09 \%$ & & & & 0.173 & & $0.18 \%$ \\
\hline & $\begin{array}{c}\text { Passenger side behind } \\
\text { the driver }\end{array}$ & 0.013 & & $0.00 \%$ & & & & 0.067 & & $0.06 \%$ \\
\hline \multirow[t]{3}{*}{ Causal vehicle type } & Passenger car & & & & 0.248 & $* *$ & $1.82 \%$ & & & \\
\hline & Pickup & & & & 0.033 & & $0.08 \%$ & & & \\
\hline & SUV & & & & 0.157 & & $0.47 \%$ & & & \\
\hline \multirow[t]{3}{*}{ Noncausal vehicle type } & Passenger car & -0.454 & $* * *$ & $-0.63 \%$ & & & & & & \\
\hline & Pickup & -0.127 & & $-0.09 \%$ & & & & & & \\
\hline & SUV & -0.389 & * & $-0.23 \%$ & & & & & & \\
\hline \multirow{2}{*}{$\begin{array}{l}\text { Scale parameters for random } \\
\text { parameters in precrash } \\
\text { actions }\end{array}$} & Dark without lighting & 3.364 & * & & & & & & & \\
\hline & Turn lane present & 2.046 & $* * *$ & & & & & & & \\
\hline (2) & Male & 1.694 & $* * *$ & 1.876 & $* * *$ & & & & & \\
\hline \multirow{7}{*}{ Summary statistics } & Number of observations & \multicolumn{9}{|c|}{10,750} \\
\hline & $\begin{array}{c}\text { Log likelihood at zero } L \\
(0)\end{array}$ & \multicolumn{9}{|c|}{$-12,143.177$} \\
\hline & $\begin{array}{l}\text { Log likelihood at } \\
\text { convergence } L(\beta)\end{array}$ & \multicolumn{9}{|c|}{$-10,184.482$} \\
\hline & Pseudo- $R 2$ & \multirow{2}{*}{\multicolumn{9}{|c|}{0.161}} \\
\hline & Likelihood-ratio test (vs. & \multirow{2}{*}{\multicolumn{9}{|c|}{ Prob. $=0.000$}} \\
\hline & $\begin{array}{c}\text { regular multinomial } \\
\text { logit) }\end{array}$ & & & & & & & & & \\
\hline & AIC & \multicolumn{9}{|c|}{$20,485.0$} \\
\hline
\end{tabular}

at stop sign), this type of crash is associated with an even greater likelihood of exacerbated injury severity (an increase by 18.61 percentage points). This increased positive correlation also applies to some other contributing factors such as "turn lane at present," "at-fault driver speeding," "at-fault driverDUI," and "collision impact point at bumpers or driver door."
On the contrary, some other factors are negatively associated with injury severity in the injury severity model. However, their indirect MEs are positive, meaning their association magnitudes with injury severity are reduced (e.g., at-fault male driver, causal vehicle driver aged 22 to 31 years old, collision impact point at the front and back 
TABLE 7: Random-parameter ordered logit model of injury severity for side impact crashes at T-junctions.

\begin{tabular}{|c|c|c|c|c|c|c|c|c|}
\hline \multirow{2}{*}{$\begin{array}{l}Y 2=\mathrm{T} \text {-junction crash injury severity } \\
\text { Variables and description }\end{array}$} & & \multicolumn{2}{|c|}{$\begin{array}{c}\text { Model } \\
\text { estimates }\end{array}$} & \multicolumn{5}{|c|}{ Marginal effects } \\
\hline & & $\beta$ & $\mathrm{O}$ & $C$ & $B$ & $A$ & $K$ & \\
\hline Constant & & 0.128 & & & & & & \\
\hline \multirow{2}{*}{$\begin{array}{l}\text { Precrash actions (base: other } \\
\text { behaviors) }\end{array}$} & Ran stop sign & 0.844 & $* * *$ & $-19.07 \%$ & $5.85 \%$ & $7.73 \%$ & $5.02 \%$ & $0.48 \%$ \\
\hline & $\begin{array}{l}\text { Failed to yield at stop sign } \\
0.262 \\
\end{array}$ & $\begin{array}{l}0.208 \\
* * * \\
\end{array}$ & $\begin{array}{c}* * * \\
-5.37 \% \\
\end{array}$ & $\begin{array}{c}-4.09 \% \\
2.00 \% \\
\end{array}$ & $\begin{array}{l}1.59 \% \\
2.08 \% \\
\end{array}$ & $\begin{array}{l}1.56 \% \\
1.18 \% \\
\end{array}$ & $\begin{array}{l}0.86 \% \\
0.11 \% \\
\end{array}$ & $0.08 \%$ \\
\hline Urban & Yes & -0.442 & $* * *$ & $9.14 \%$ & $-3.35 \%$ & $-3.56 \%$ & $-2.05 \%$ & $-0.19 \%$ \\
\hline \multirow{2}{*}{$\begin{array}{l}\text { Crash location (base: other crash } \\
\text { locations) }\end{array}$} & Open country & 0.220 & $*$ & $-4.44 \%$ & $1.68 \%$ & $1.71 \%$ & $0.96 \%$ & $0.09 \%$ \\
\hline & $\begin{array}{c}\text { Residential area } \\
0.092\end{array}$ & -0.043 & $-1.82 \%$ & $\begin{array}{l}0.85 \% \\
0.70 \% \\
\end{array}$ & $\begin{array}{c}-0.33 \% \\
0.70 \%\end{array}$ & $\begin{array}{c}-0.32 \% \\
0.39 \%\end{array}$ & $\begin{array}{l}-0.18 \% \\
0.04 \%\end{array}$ & $-0.02 \%$ \\
\hline \multirow{2}{*}{$\begin{array}{l}\text { Lighting condition (base: other } \\
\text { lighting conditions) }\end{array}$} & Daylight & -0.196 & $*$ & $3.96 \%$ & $-1.50 \%$ & $-1.53 \%$ & $-0.86 \%$ & $-0.08 \%$ \\
\hline & $\begin{array}{c}\text { Dark without lighting } \\
0.089 \\
\end{array}$ & -0.039 & $-1.79 \%$ & $\begin{array}{l}0.76 \% \\
0.69 \% \\
\end{array}$ & $\begin{array}{c}-0.30 \% \\
0.69 \% \\
\end{array}$ & $\begin{array}{c}-0.29 \% \\
0.39 \% \\
\end{array}$ & $\begin{array}{l}-0.16 \% \\
0.04 \%\end{array}$ & $-0.01 \%$ \\
\hline $\begin{array}{l}\text { Turn lane present } \\
\text { At-fault driver_speeding } \\
\text { At-fault driver_DUI } \\
\text { Gender }\end{array}$ & $\begin{array}{c}\text { Yes } \\
\text { Yes } \\
\text { Yes } \\
\text { Male } \\
\end{array}$ & $\begin{array}{c}0.183 \\
0.916 \\
0.919 \\
-0.250\end{array}$ & $\begin{array}{l}* * * \\
* * * \\
* * * \\
* * *\end{array}$ & $\begin{array}{c}-3.67 \% \\
-20.94 \% \\
-21.03 \% \\
4.93 \% \\
\end{array}$ & $\begin{array}{c}1.40 \% \\
6.16 \% \\
6.16 \% \\
-1.91 \% \\
\end{array}$ & $\begin{array}{c}1.41 \% \\
8.54 \% \\
8.58 \% \\
-1.88 \% \\
\end{array}$ & $\begin{array}{c}0.79 \% \\
5.69 \% \\
5.74 \% \\
-1.04 \% \\
\end{array}$ & $\begin{array}{c}0.07 \% \\
0.55 \% \\
0.55 \% \\
-0.09 \% \\
\end{array}$ \\
\hline \multirow[b]{2}{*}{ At-fault age } & 21 years old or younger & -0.186 & $* *$ & $3.59 \%$ & $-1.42 \%$ & $-1.36 \%$ & $-0.74 \%$ & $-0.07 \%$ \\
\hline & $\begin{array}{c}\text { 22 31 years old } \\
32 \sim 41 \text { years old } \\
42 \sim 51 \text { years old } \\
52 \sim 61 \text { years old } \\
-0.151 \\
\end{array}$ & $\begin{array}{l}-0.190 \\
-0.061 \\
-0.045 \\
-0.176\end{array}$ & $\begin{array}{c}* \\
2.89 \% \\
\end{array}$ & $\begin{array}{c}3.64 \% \\
1.20 \% \\
0.87 \% \\
3.36 \% \\
-1.15 \% \\
\end{array}$ & $\begin{array}{l}-1.44 \% \\
-0.47 \% \\
-0.34 \% \\
-1.34 \% \\
-1.09 \% \\
\end{array}$ & $\begin{array}{l}-1.38 \% \\
-0.46 \% \\
-0.33 \% \\
-1.27 \% \\
-0.59 \% \\
\end{array}$ & $\begin{array}{l}-0.75 \% \\
-0.25 \% \\
-0.18 \% \\
-0.69 \% \\
-0.05 \% \\
\end{array}$ & $\begin{array}{l}-0.07 \% \\
-0.02 \% \\
-0.02 \% \\
-0.06 \%\end{array}$ \\
\hline \multirow[b]{2}{*}{ Point of impact } & Front passenger side & -0.209 & $* *$ & $3.96 \%$ & $-1.59 \%$ & $-1.49 \%$ & $-0.81 \%$ & $-0.07 \%$ \\
\hline & $\begin{array}{c}\text { Back passenger side } \\
\text { Bumper } \\
\text { Driver door } \\
-1.012 \\
\end{array}$ & $\begin{array}{c}-0.613 \\
1.013 \\
0.003 \\
* * * \\
\end{array}$ & $\begin{array}{l}* * * \\
* * * \\
16.01 \% \\
\end{array}$ & $\begin{array}{c}10.59 \% \\
-20.19 \% \\
-0.07 \% \\
-6.94 \% \\
\end{array}$ & $\begin{array}{c}-4.46 \% \\
7.45 \% \\
0.03 \% \\
-5.83 \% \\
\end{array}$ & $\begin{array}{c}-3.91 \% \\
7.82 \% \\
0.03 \% \\
-2.98 \% \\
\end{array}$ & $\begin{array}{c}-2.04 \% \\
4.51 \% \\
0.02 \% \\
-0.26 \% \\
\end{array}$ & $\begin{array}{c}-0.18 \% \\
0.41 \% \\
0.00 \%\end{array}$ \\
\hline Causal vehicle type & Passenger car & $\begin{array}{l}-0.435 \\
-0.590 \\
* * * \\
\end{array}$ & $\begin{array}{l}* * * \\
9.67 \% \\
\end{array}$ & $\begin{array}{l}10.57 \% \\
-3.94 \% \\
\end{array}$ & $\begin{array}{l}-3.31 \% \\
-4.36 \% \\
-3.62 \% \\
\end{array}$ & $\begin{array}{l}-3.31 \% \\
-3.94 \% \\
-1.94 \% \\
\end{array}$ & $\begin{array}{l}-1.85 \% \\
-2.09 \% \\
-0.17 \% \\
\end{array}$ & $\begin{array}{l}-0.17 \% \\
-0.19 \% \\
\end{array}$ \\
\hline Noncausal vehicle type & Passenger car & $\begin{array}{l}-0.599 \\
-0.871 \\
* * * \\
\end{array}$ & $\begin{array}{c}* * * \\
* * * \\
11.30 \% \\
\end{array}$ & $\begin{array}{l}11.83 \% \\
14.93 \% \\
-4.65 \% \\
\end{array}$ & $\begin{array}{l}-4.53 \% \\
-6.25 \% \\
-4.22 \% \\
\end{array}$ & $\begin{array}{l}-4.53 \% \\
-5.52 \% \\
-2.24 \% \\
\end{array}$ & $\begin{array}{l}-2.54 \% \\
-2.90 \% \\
-0.20 \% \\
\end{array}$ & $\begin{array}{l}-0.23 \% \\
-0.26 \%\end{array}$ \\
\hline $\begin{array}{l}\text { Scale parameters for random } \\
\text { parameters }\end{array}$ & Failed to yield at stop sign & 0.097 & $* * *$ & & & & & \\
\hline $\begin{array}{l}\mathrm{Mu}(01) \\
\mathrm{Mu}(02) \\
\mathrm{Mu}(03)\end{array}$ & & $\begin{array}{l}0.819 \\
2.003 \\
4.588 \\
\end{array}$ & $\begin{array}{l}* * * \\
* * * \\
* * * \\
\end{array}$ & & & & & \\
\hline Summary statistics & $\begin{array}{c}\text { Number of observations } \\
\text { Log likelihood at zero } L(0) \\
\text { Log likelihood at convergence } L \\
(\beta) \\
\text { Pseudo- } R 2 \\
\text { Likelihood-ratio test (vs. regular } \\
\text { ordered logit) } \\
\text { AIC }\end{array}$ & & & & $\begin{array}{c}10,750 \\
10,403.85 \\
-9,747.577 \\
0.063\end{array}$ & & & \\
\hline
\end{tabular}


TABLE 8: Behavioral pathway analysis of four-way intersections with direct and indirect marginal effects.

\begin{tabular}{|c|c|c|c|c|c|c|c|c|c|c|c|c|}
\hline Variable $(X)$ & & $\begin{array}{c}\text { Direct } \\
\text { ME on } \\
Y_{2}\end{array}$ & $\begin{array}{c}\mu_{X} \\
\text { for } \\
Y_{1} \\
\text { RSS }\end{array}$ & $\begin{array}{c}\mu_{X} \text { for } \\
Y_{1} \\
\text { FYSS }\end{array}$ & $\begin{array}{l}\text { ME on } \\
Y_{1} \text { RSS }\end{array}$ & $\begin{array}{c}\text { ME on } \\
Y_{1} \\
\text { FYSS }\end{array}$ & $\begin{array}{c}\mu_{Y_{1}} \\
\text { for } \\
Y_{2}\end{array}$ & $\begin{array}{l}\text { ME of } \\
Y_{1} \\
\text { RSS } \\
\text { on } Y_{2}\end{array}$ & $\begin{array}{l}\text { ME of } \\
Y_{1} \\
\text { FYSS } \\
\text { on } Y_{2}\end{array}$ & $\begin{array}{l}\text { Indirect } \\
\text { ME on } Y_{2} \\
\text { through } \\
\text { RSS }\end{array}$ & $\begin{array}{l}\text { Indirect } \\
\text { ME on } Y_{2} \\
\text { through } \\
\text { FYSS }\end{array}$ & $\begin{array}{l}\text { Total } \\
\text { ME on } \\
Y_{2}\end{array}$ \\
\hline Urban & Yes & $-12.01 \%$ & & & & & 31.75 & 17.00 & 2.03 & 0.00 & $0.00 \%$ & $-12.01 \%$ \\
\hline \multirow{2}{*}{$\begin{array}{l}\text { Crash location } \\
\text { (base: other crash } \\
\text { locations) }\end{array}$} & $\begin{array}{l}\text { Open } \\
\text { country }\end{array}$ & $6.45 \%$ & & & & & 31.75 & 17.00 & 2.03 & 0.00 & $0.00 \%$ & $6.45 \%$ \\
\hline & $\begin{array}{l}\text { Residential } \\
\text { area }\end{array}$ & $-5.25 \%$ & 10.51 & & $2.61 \%$ & & 31.75 & 17.00 & 2.03 & 3.06 & $0.00 \%$ & $-2.19 \%$ \\
\hline Shopping center & $-4.67 \%$ & & & & & 31.75 & 17.00 & 2.03 & 0.00 & $0.00 \%$ & $-4.67 \%$ & \\
\hline \multirow{3}{*}{$\begin{array}{r}\text { Roadway } \\
\text { condition } \\
\text { Wet }\end{array}$} & Dry & & & & & & 31.75 & 17.00 & 2.03 & 0.00 & $0.00 \%$ & $0.00 \%$ \\
\hline & & & & & & 31.75 & 17.00 & 2.03 & 0.00 & $0.00 \%$ & $0.00 \%$ & \\
\hline & Daylight & & & 51.68 & & $4.89 \%$ & 31.75 & 17.00 & 2.03 & 0.00 & $2.70 \%$ & $2.70 \%$ \\
\hline $\begin{array}{l}\text { Lighting } \\
\text { condition }\end{array}$ & $\begin{array}{c}\text { Dark } \\
\text { without } \\
\text { lighting }\end{array}$ & & 14.37 & & $0.37 \%$ & & 31.75 & 17.00 & 2.03 & 2.62 & $0.00 \%$ & $2.62 \%$ \\
\hline $\begin{array}{l}\text { Dark with } \\
\text { lighting }\end{array}$ & & & & & & 31.75 & 17.00 & 2.03 & 0.00 & $0.00 \%$ & $0.00 \%$ & \\
\hline $\begin{array}{l}\text { Roadway } \\
\text { geometry (base: } \\
\text { curved roadway) }\end{array}$ & $\begin{array}{c}\text { Straight } \\
\text { level road }\end{array}$ & $3.24 \%$ & 12.26 & 61.44 & $12.26 \%$ & $17.96 \%$ & 31.75 & 17.00 & 2.03 & 8.06 & $7.31 \%$ & $18.61 \%$ \\
\hline $\begin{array}{l}\text { Straight road } \\
\text { with grade }\end{array}$ & & 12.26 & 61.44 & $1.65 \%$ & $2.28 \%$ & 31.75 & 17.00 & 2.03 & 2.89 & $2.02 \%$ & $4.91 \%$ & \\
\hline \multirow{5}{*}{$\begin{array}{l}\text { Turn lane present } \\
\text { No functioning } \\
\text { traffic control } \\
\text { At-fault } \\
\text { driver_speeding } \\
\text { At-fault } \\
\text { driver_DUI } \\
\text { Gender }\end{array}$} & Yes & $2.31 \%$ & 13.98 & 64.63 & $-1.38 \%$ & $-3.54 \%$ & 31.75 & 17.00 & 2.03 & 1.70 & $0.12 \%$ & $4.13 \%$ \\
\hline & Yes & & 13.62 & 68.17 & $-1.89 \%$ & $-6.66 \%$ & 31.75 & 17.00 & 2.03 & 1.39 & $-0.87 \%$ & $0.53 \%$ \\
\hline & Yes & $18.66 \%$ & & 61.48 & & $-0.37 \%$ & 31.75 & 17.00 & 2.03 & 0.00 & $1.12 \%$ & $19.79 \%$ \\
\hline & Yes & $25.39 \%$ & 12.27 & 61.19 & $-0.23 \%$ & $-0.46 \%$ & 31.75 & 17.00 & 2.03 & 1.97 & $1.09 \%$ & $28.45 \%$ \\
\hline & Male & $-3.71 \%$ & & 62.61 & & $-1.64 \%$ & 31.75 & 17.00 & 2.03 & 0.00 & $0.72 \%$ & $-2.99 \%$ \\
\hline \multirow{5}{*}{$\begin{array}{l}\text { At-fault driver } \\
\text { age }\end{array}$} & $\begin{array}{l}21 \text { years old } \\
\text { or younger }\end{array}$ & $-5.68 \%$ & & & & & 31.75 & 17.00 & 2.03 & 0.00 & $0.00 \%$ & $-5.68 \%$ \\
\hline & $\begin{array}{c}22 \sim 31 \text { years } \\
\text { old }\end{array}$ & $-4.73 \%$ & 10.90 & 64.54 & $0.53 \%$ & $-0.72 \%$ & 31.75 & 17.00 & 2.03 & 2.11 & $1.07 \%$ & $-1.55 \%$ \\
\hline & $\begin{array}{l}\text { 32 41 years } \\
\text { old }\end{array}$ & $-5.56 \%$ & & & & & 31.75 & 17.00 & 2.03 & 0.00 & $0.00 \%$ & $-5.56 \%$ \\
\hline & $\begin{array}{l}42 \sim 51 \text { years } \\
\text { old }\end{array}$ & $-5.19 \%$ & & & & & 31.75 & 17.00 & 2.03 & 0.00 & $0.00 \%$ & $-5.19 \%$ \\
\hline & $\begin{array}{c}52 \sim 61 \text { years } \\
\text { old }\end{array}$ & $-3.62 \%$ & & & & & 31.75 & 17.00 & 2.03 & 0.00 & $0.00 \%$ & $-3.62 \%$ \\
\hline $62 \sim 71$ years old & $-3.82 \%$ & & & & & 31.75 & 17.00 & 2.03 & 0.00 & $0.00 \%$ & $-3.82 \%$ & \\
\hline \multirow{4}{*}{ Point of impact } & $\begin{array}{l}\text { Front } \\
\text { passenger } \\
\text { side }\end{array}$ & $-7.47 \%$ & 13.20 & 55.94 & $0.55 \%$ & $0.33 \%$ & 31.75 & 17.00 & 2.03 & 2.51 & $1.25 \%$ & $-3.71 \%$ \\
\hline & $\begin{array}{c}\text { Back } \\
\text { passenger } \\
\text { side }\end{array}$ & $-17.93 \%$ & 13.20 & & $0.27 \%$ & & 31.75 & 17.00 & 2.03 & 2.38 & $0.00 \%$ & $-15.55 \%$ \\
\hline & Bumper & $16.76 \%$ & & 55.94 & & $4.57 \%$ & 31.75 & 17.00 & 2.03 & 0.00 & $2.68 \%$ & $19.43 \%$ \\
\hline & Driver door & $9.57 \%$ & 13.20 & 55.94 & $0.25 \%$ & $0.31 \%$ & 31.75 & 17.00 & 2.03 & 2.37 & $1.24 \%$ & $13.18 \%$ \\
\hline $\begin{array}{l}\text { Passenger side } \\
\text { behind the driver }\end{array}$ & $-12.64 \%$ & & & & & 31.75 & 17.00 & 2.03 & 0.00 & $0.00 \%$ & $-12.64 \%$ & \\
\hline
\end{tabular}


TABLE 8: Continued.

\begin{tabular}{|c|c|c|c|c|c|c|c|c|c|c|c|c|}
\hline Variable $(X)$ & & $\begin{array}{c}\text { Direct } \\
\text { ME on } \\
Y_{2}\end{array}$ & $\begin{array}{c}\mu_{X} \\
\text { for } \\
Y_{1} \\
\text { RSS }\end{array}$ & $\begin{array}{c}\mu_{X} \text { for } \\
Y_{1} \\
\text { FYSS }\end{array}$ & $\begin{array}{l}\text { ME on } \\
Y_{1} \text { RSS }\end{array}$ & $\begin{array}{c}\text { ME on } \\
Y_{1} \\
\text { FYSS }\end{array}$ & $\begin{array}{c}\mu_{Y_{1}} \\
\text { for } \\
Y_{2}\end{array}$ & $\begin{array}{c}\text { ME of } \\
Y_{1} \\
\text { RSS } \\
\text { on } Y_{2}\end{array}$ & $\begin{array}{c}\text { ME of } \\
Y_{1} \\
\text { FYSS } \\
\text { on } Y_{2}\end{array}$ & $\begin{array}{l}\text { Indirect } \\
\text { ME on } Y_{2} \\
\text { through } \\
\text { RSS }\end{array}$ & $\begin{array}{c}\text { Indirect } \\
\text { ME on } Y_{2} \\
\text { through } \\
\text { FYSS }\end{array}$ & $\begin{array}{c}\text { Total } \\
\text { ME on } \\
Y_{2}\end{array}$ \\
\hline $\begin{array}{l}\text { Causal vehicle } \\
\text { type }\end{array}$ & $\begin{array}{c}\text { Passenger } \\
\text { car }\end{array}$ & $-3.06 \%$ & & 55.27 & & $2.81 \%$ & 31.75 & 17.00 & 2.03 & 0.00 & $2.07 \%$ & $-0.99 \%$ \\
\hline $\begin{array}{l}\text { Pickup } \\
\text { SUV }\end{array}$ & $-4.53 \%$ & & $\begin{array}{l}55.27 \\
55.27\end{array}$ & & $\begin{array}{l}0.85 \% \\
1.26 \%\end{array}$ & $\begin{array}{l}31.75 \\
31.75\end{array}$ & $\begin{array}{l}17.00 \\
17.00\end{array}$ & $\begin{array}{l}2.03 \\
2.03\end{array}$ & $\begin{array}{l}0.00 \\
0.00\end{array}$ & $\begin{array}{l}1.41 \% \\
1.55 \%\end{array}$ & $\begin{array}{c}-3.12 \% \\
1.55 \%\end{array}$ & \\
\hline \multirow{2}{*}{$\begin{array}{l}\text { Noncausal } \\
\text { vehicle type }\end{array}$} & $\begin{array}{c}\text { Passenger } \\
\text { car }\end{array}$ & $-7.31 \%$ & & & & & 31.75 & 17.00 & 2.03 & 0.00 & $0.00 \%$ & $-7.31 \%$ \\
\hline & $\begin{array}{l}\text { Pickup } \\
\text { SUV }\end{array}$ & $\begin{array}{c}-10.40 \% \\
-6.21 \%\end{array}$ & & & & & $\begin{array}{l}31.75 \\
31.75\end{array}$ & $\begin{array}{l}17.00 \\
17.00\end{array}$ & $\begin{array}{l}2.03 \\
2.03\end{array}$ & $\begin{array}{l}0.00 \\
0.00\end{array}$ & $\begin{array}{l}0.00 \% \\
0.00 \%\end{array}$ & $\begin{array}{c}-10.40 \% \\
-6.21 \%\end{array}$ \\
\hline
\end{tabular}

Notes: $Y_{2}$ is the $K A B C$ injury; $Y_{1}$ is one of "ran stop sign (RSS)" or "failed to yield at stop sign (FYSS)"; $\mu_{X}$ is the probability of $Y_{1}$ when contributing factor $X$ is at the base; $\mu_{Y_{1}}$ is the probability of $K A B C$ injury when precrash behavior $Y_{1}$ is at the base (i.e., "other behaviors"); indirect ME of $X$ on $Y_{2}=\left(\mu_{X}+\operatorname{ME}\right.$ of $X$ on $\left.Y_{1}\right) *\left(\mu_{Y_{1}}+\operatorname{ME}\right.$ of $Y_{1}$ on $\left.Y_{2}\right)-\mu_{x} * \mu_{Y_{1}}$; total ME on $Y_{2}=\operatorname{direct} \operatorname{ME}$ of $X$ on $Y_{2}+$ indirect ME of $X$ on $Y_{2}$; some cells are empty due to the insignificant estimates $(p$ value $>0.1)$ from the models.

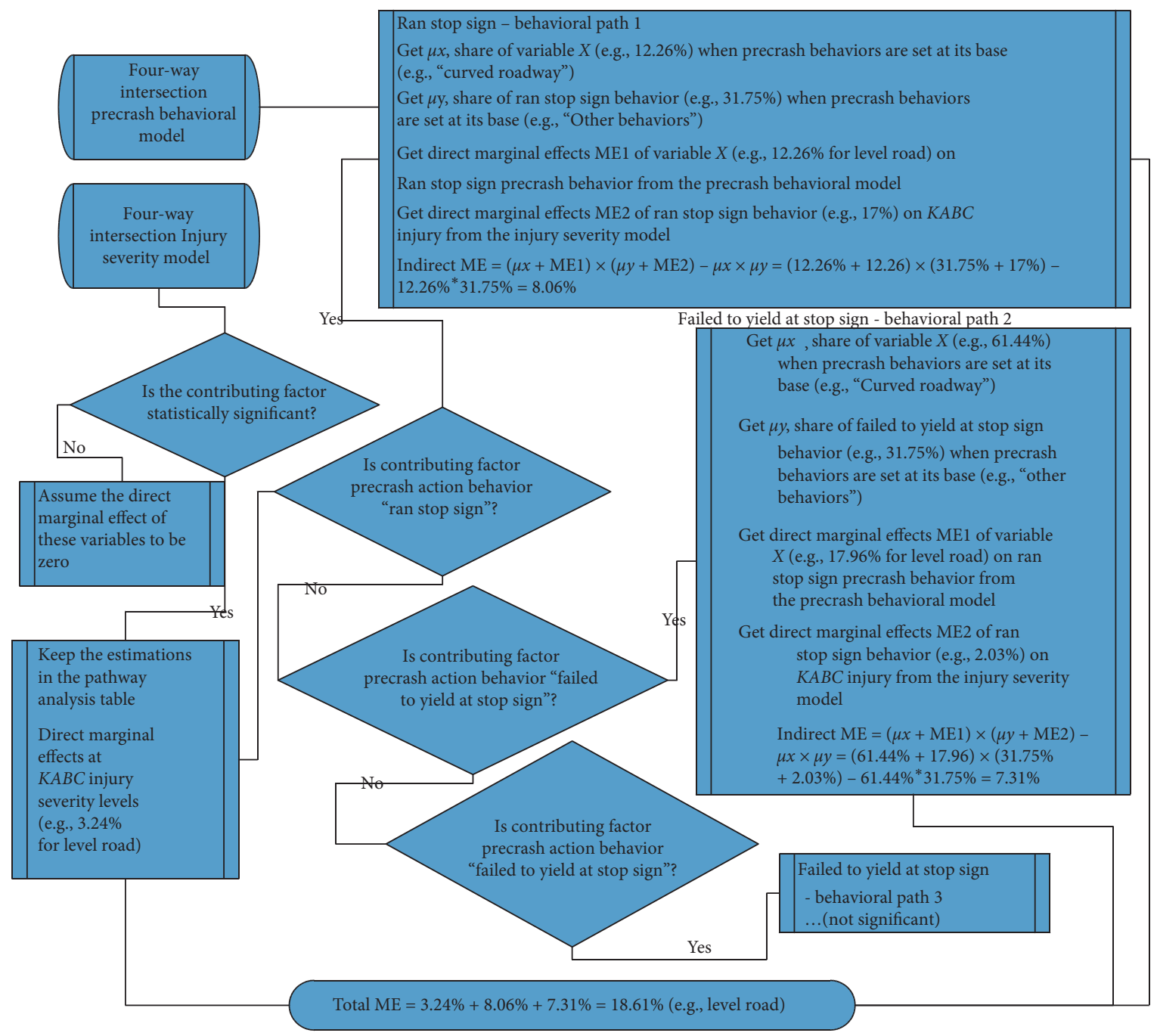

Figure 2: The logical procedure to calculate the total marginal effects based on the direct marginal effects through the injury severity model and the indirect marginal effects through the precrash behavior model. 


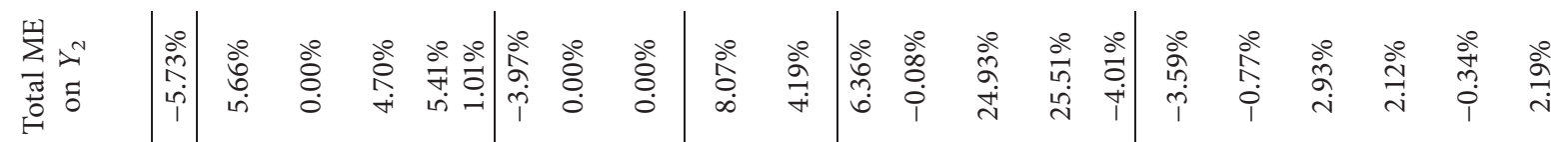

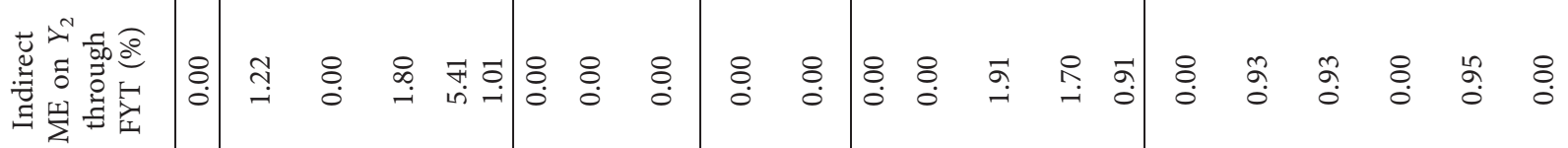

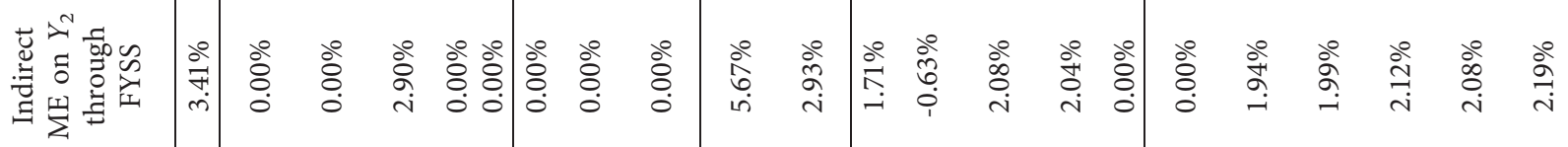

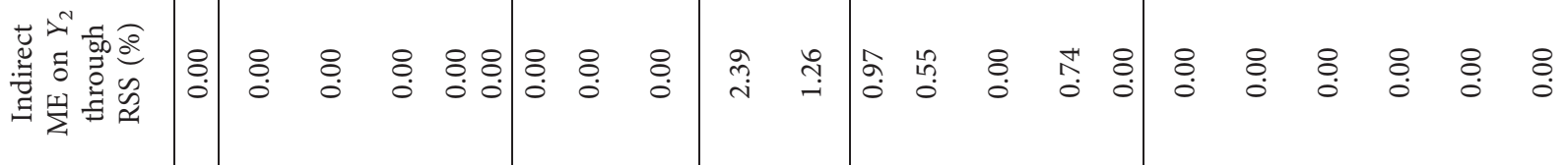

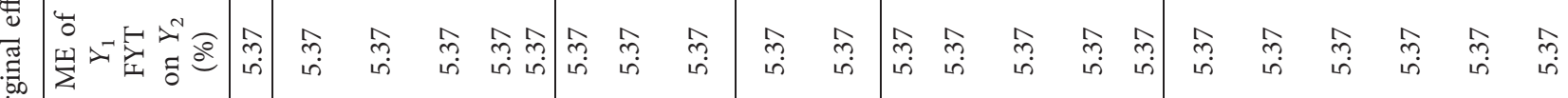

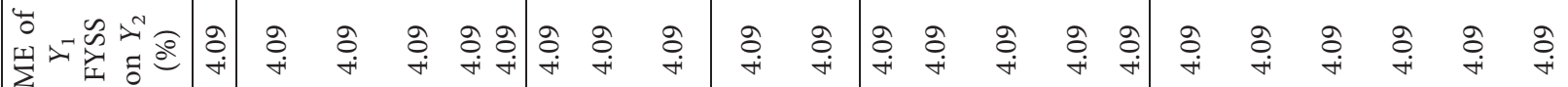
पू山ैخ

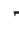

(1)

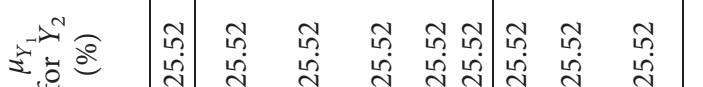

\begin{tabular}{|c|c|c|c|}
\hline 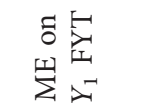 & & 宅 & ڤ్̀ें \\
\hline 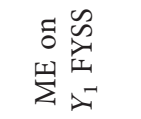 & $\left|\begin{array}{l}0 \\
\dot{0} \\
\stackrel{\leftrightarrow}{+}\end{array}\right|$ & & छे \\
\hline 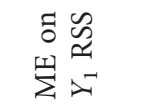 & & & \\
\hline 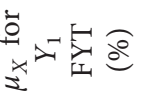 & & $\underset{I}{\mathcal{I}}$ & $\begin{array}{l}\mathcal{Y} \\
\underset{+}{ }\end{array}$ \\
\hline 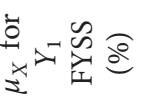 & $\begin{array}{c}\delta \\
\dot{1} \\
\dot{1}\end{array}$ & & ঙุ. \\
\hline
\end{tabular}

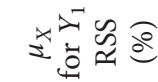

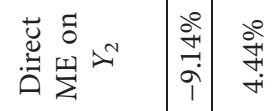

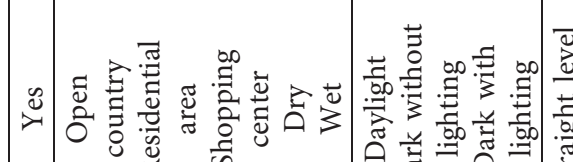

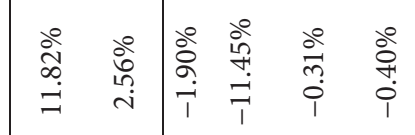

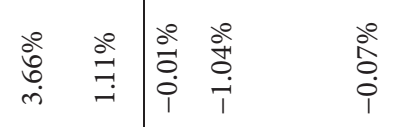

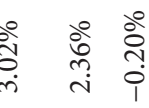

ก) กิ กิ กิ กิ กิ กี

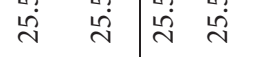

.

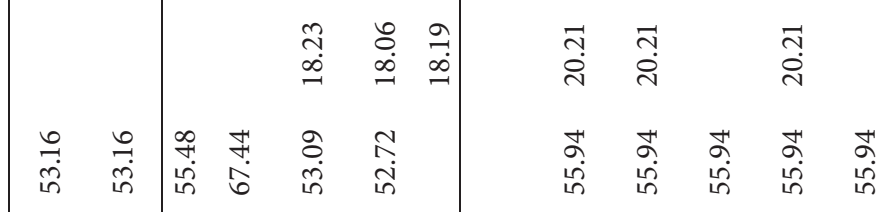

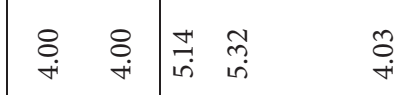

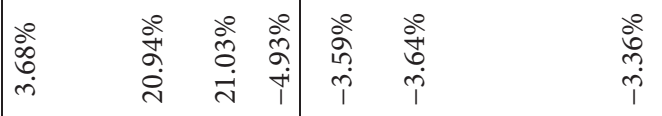




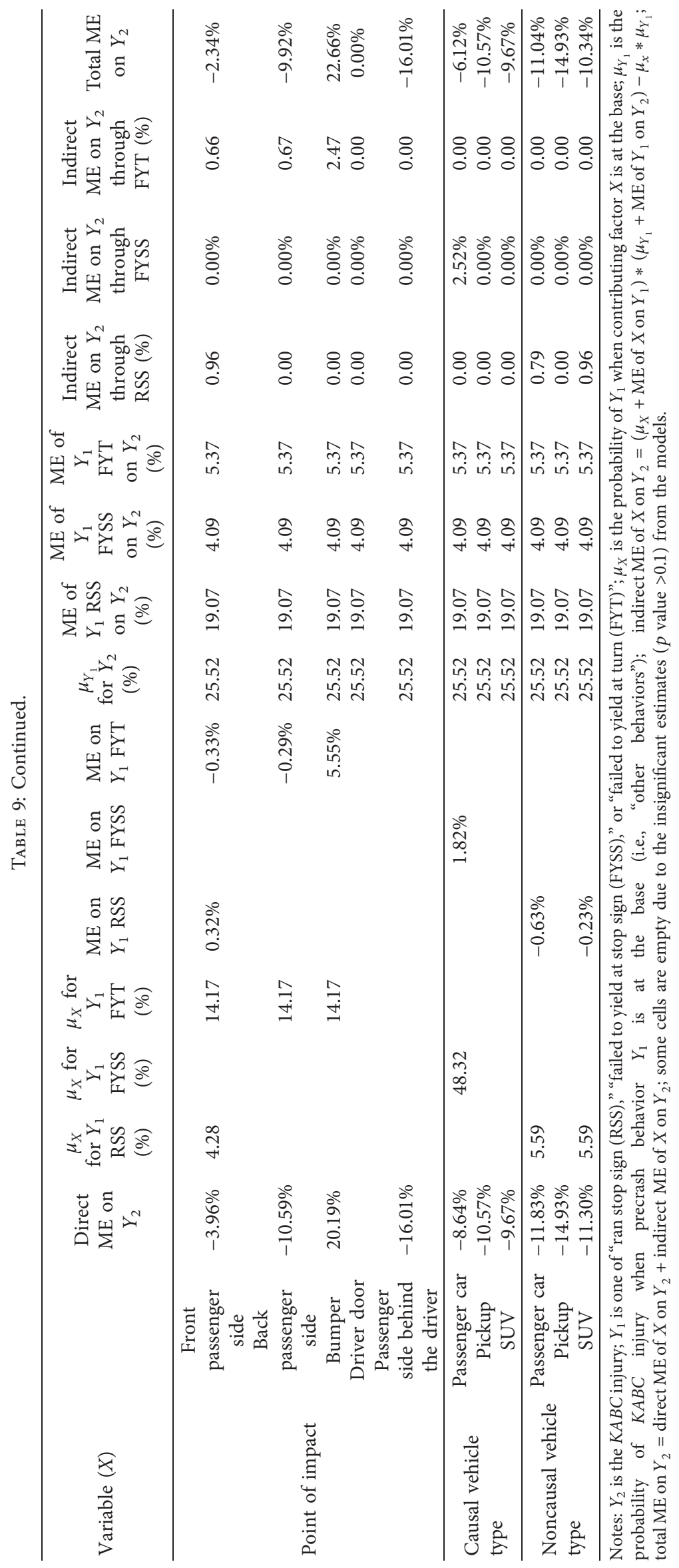


passenger side, and causal vehicle type-passenger car or pickup). Noticeably, some variables, such as lighting condition-dark and unlit, are not statistically significantly correlated with injury severity, but they are significantly associated with dangerous precrash behaviors (e.g., ran stop sign). Thus, the behavioral pathway is important in the sense to highlight these contributing factors that are indirectly correlated to crash injury severity at four-way intersections.

4.3. T-Junction Behavioral Pathway. The behavioral pathway analysis is applied to the T-junction side impact crashes based on the same quantifying process as the four-way intersection (see Table 9). Three significant behavioral pathways have been identified through "ran stop sign," "failed to yield at the turn," and "failed to yield at stop sign." In addition to the findings from the traditional injury severity model, the behavioral pathway analysis provides extra implications in terms of the indirect and total marginal effects. For example, if the crash occurred at a T-Junction with a turn lane, then the likelihood of the crash to be an injury crash is increased by $6.36 \%$ if the indirect effect is considered through the precrash behaviors (e.g., failed to yield at the turn, ran stop sign, and failed to yield at the stop sign), which is much greater than the $3.68 \%$ points' increase of the marginal effects without considering behavioral pathways. This kind of stronger positive correlation with injury severity at T-junctions also applies to some other contributing factors including open country crash location, at-fault driver speeding, at-fault driver driving under the influence, and collision impact point at bumpers.

Some other factors were found to be negatively associated with injury severity, but their indirect MEs are positive, indicating that their correlation magnitudes with injury severity are lessened (e.g., urban area, at-fault male driver, at-fault drivers aged 22 to 31 and 52 to 61 years old, collision impact point-front and back passenger sides, causal vehicle type-passenger car, and noncausal vehicle type-passenger car or SUV). It should be noted that some variables, such as straight level road and dry or wet roadway condition, are not statistically significantly correlated with injury severity, but they are significantly associated with dangerous precrash behaviors (e.g., ran stop sign or failed to yield at turn), which again confirmed the usefulness and benefit of applying the pathway analysis to investigate the crash injury outcomes.

\section{Conclusions}

This study performs a behavioral path analysis to understand the factors that influence driver behaviors at unsignalized intersections and how these factors influence the severity of side impact crashes. Models are built to segment the correlates of precrash actions and side impact crash severity by quantifying the indirect marginal effects of various crash contributing factors through specific traffic violation behaviors at unsignalized four-way intersections and $\mathrm{T}$ junctions. The results are useful in understanding how precrash actions and other crash factors influence the severity of side impact crash outcomes. The study was based on
2009-2016 crash data obtained from the Critical Analysis Reporting Environment (CARE) system developed by the Center for Advanced Public Safety at the University of Alabama.

By developing a random-parameter logit model, this paper unravels significant associations between precrash actions and number of crash contributing factors (e.g., lighting conditions and land use). Additionally, randomparameter ordered logit models were developed to investigate the contributing factors that are directly associated with side impact crash outcomes. Through behavioral pathway analysis, the marginal effects of the contributing factors on precrash actions and crash injury severity were combined to show how the behavioral pathways influence injury severities. For example, the total marginal effect of straight and flat roadways (compared with curved roadway) on four-way intersection crash injury severity increases from $3.24 \%$ to $18.61 \%$ by adding the indirect marginal effect through the precrash behaviors (e.g., ran stop sign and failed to yield at stop sign). The findings from this study contribute to the larger body of safety literature on understanding the associations between crash contributing factors and crash outcomes by unraveling complex relationships in the role of precrash actions.

This study attempted to investigate the behavioral pathways through which side impact crashes occur at unsignalized intersections and focused on four-way intersections and $\mathrm{T}$ junctions in Alabama. For the purpose of this study, only three precrash actions were considered. However, it is possible that these precrash actions may not be the only ones that significantly influence crash outcomes at these intersections. Besides, the assignment of fault for these crashes solely depends on the reporting police officer, and limited information is presented regarding the drivers not at fault. Also, lower injury crashes do not go through rigorous investigation to identify which driver is truly at fault. As such, this could bias the research findings considering that lower injury crashes made up the highest proportion of the data used. In spite of these limitations, the findings of this study are consistent with previous findings and provide adequate information for informed decision-making to reduce the incidence and severity of side impact crashes at unsignalized intersections.

\section{Data Availability}

The data used to support the findings of this study are available from the corresponding author upon request.

\section{Conflicts of Interest}

The authors declare that they have no conflicts of interest.

\section{Acknowledgments}

The authors would like to thank Alabama Transportation Institute for supporting this study and the Center for Advanced Public Safety at the University of Alabama for the crash data used in the study. 


\section{References}

[1] National Highway Traffic Safety Administration, Fatality Analysis Reporting System (Fars), National Highway Traffic Safety Administration, Washington, D.C., USA, 2019.

[2] S. A. Biancardo, F. Russo, D. Žilionienè, W. Zhang, and W. Zhang, "Rural two-lane two-way three-leg and four-leg stop-controlled intersections: predicting road safety effects," The Baltic Journal of Road and Bridge Engineering, vol. 12, no. 2, pp. 117-126, 2017.

[3] S. A. Biancardo, F. Russo, W. Zhang, and R. Veropalumbo, "Design criteria for improving safety performance of rural intersections," Journal of Advanced Transportation, vol. 2019, Article ID 1232058, 2019.

[4] K. Haleem, P. Alluri, and A. Gan, "Analyzing pedestrian crash injury severity at signalized and non-signalized locations," Accident Analysis \& Prevention, vol. 81, pp. 14-23, 2015.

[5] K. Obeng, "Gender differences in injury severity risks in crashes at signalized intersections," Accident Analysis \& Prevention, vol. 43, no. 4, pp. 1521-1531, 2011.

[6] C.-W. Pai, "Motorcyclist injury severity in angle crashes at Tjunctions: identifying significant factors and analysing what made motorists fail to yield to motorcycles," Safety Science, vol. 47, no. 8, pp. 1097-1106, 2009.

[7] K. Haleem and M. Abdel-Aty, "Examining traffic crash injury severity at unsignalized intersections," Journal of Safety Research, vol. 41, no. 4, pp. 347-357, 2010.

[8] C. Wang, L. Lu, and J. Lu, "Statistical analysis of bicyclists' injury severity at unsignalized intersections," Traffic Injury Prevention, vol. 16, no. 5, pp. 507-512, 2015.

[9] Z. Li, C. Chen, Y. Ci et al., "Examining driver injury severity in intersection-related crashes using cluster Analysis and hierarchical bayesian models," Accident Analysis \& Prevention, vol. 120, pp. 139-151, 2018.

[10] R. R.-ha Wahi, N. Haworth, A. Debnath, and M. King, "Influence of type of traffic control on injury severity in bicycle-motor vehicle crashes at intersections," Transportation Research Record, vol. 2672, no. 38, pp. 199-209, 2018.

[11] K. Wang, T. Bhowmik, S. Yasmin, S. Zhao, N. Eluru, and E. Jackson, "Multivariate copula temporal modeling of intersection crash consequence metrics: a joint estimation of injury severity, crash type, vehicle damage and driver error," Accident Analysis \& Prevention, vol. 125, pp. 188-197, 2019.

[12] P. Savolainen, F. Mannering, D. Lord, and M. Quddus, "The statistical analysis of crash-injury severities: a review and assessment of methodological alternatives," Accident Analysis and Prevention, vol. 43, no. 5, pp. 1666-1676, 2011.

[13] F. L. Mannering and C. R. Bhat, "Analytic methods in accident research: methodological frontier and future directions," Analytic Methods in Accident Research, vol. 1, pp. 1-22, 2014.

[14] J. Liu, S. Jones, E. K. Adanu, and X. Li, "Behavioral pathways in bicycle-motor vehicle crashes: From contributing factors, pre-crash actions, to injury severities," Journal of Safety Research, 2021, In press.

[15] X. Li, Q. Hu, J. Liu et al., "Pathway analysis of relationships among community development, active travel behavior, body mass index, and self-rated health," International Journal of Sustainable Transportation, pp. 1-7, 2021.

[16] F. Chang, P. Xu, H. Zhou, A. Hs, H. Huang, and A. H. S. Huang, "Investigating injury severities of motorcycle riders: a two-step method integrating latent class cluster analysis and random parameters logit model," Accident Analysis \& Prevention, vol. 131, pp. 316-326, 2019.
[17] F. Chen, M. Song, and X. Ma, "Investigation on the injury severity of drivers in rear-end collisions between cars using a random parameters bivariate ordered probit model," International Journal of Environmental Research and Public Health, vol. 16, no. 14, p. 2632, 2019.

[18] Y. Guo, Y. Wu, J. Lu, and J. Zhou, "Modeling the unobserved heterogeneity in e-bike collision severity using full Bayesian random parameters multinomial logit regression," Sustainability, vol. 11, no. 7, p. 2071, 2019.

[19] Z. Li, Q. Wu, Y. Ci, C. Chen, X. Chen, and G. Zhang, "Using latent class analysis and mixed logit model to explore risk factors on driver injury severity in single-vehicle crashes," Accident Analysis \& Prevention, vol. 129, pp. 230-240, 2019.

[20] M. Waseem, A. Ahmed, and T. U. Saeed, "Factors affecting motorcyclists' injury severities: an empirical assessment using random parameters logit model with heterogeneity in means and variances," Accident Analysis \& Prevention, vol. 123, pp. 12-19, 2019.

[21] J. Wang, H. Huang, P. Xu, S. Xie, and S. C. Wong, "Random parameter probit models to analyze pedestrian red-light violations and injury severity in pedestrian-motor vehicle crashes at signalized crossings," Journal of Transportation Safety \& Security, vol. 12, no. 6, pp. 818-837, 2020.

[22] H. Zhou, C. Yuan, N. Dong, S. C. Wong, and P. Xu, "Severity of passenger injuries on public buses: a comparative analysis of collision injuries and non-collision injuries," Journal of Safety Research, vol. 74, pp. 55-69, 2020. 